\title{
Türkiye'deki Çevrimiçi Evlilik Siteleri: Medyanın Benlik Sunumuna Etkisinin Toplumsal Cinsiyet Odaklı Bir Analizi
}

\author{
Hülya Uğur Tanrı̈ver \\ Aylin Sunam
}

profesör, giresun üniversitesi, tirebolu iletișim fakültesi, radyo televizyon ve sinema bölümü hulyatanriover@gmail.com

doktora öğrencisi, paris 1 pantheon sorbonne ve galatasaray üniversitesi aylin.sunam@gmail.com

\begin{abstract}
Marriage Websites in Turkey: A gender oriented analysis of media's influence on self-presentation

In this article, the profile photos of 1200 users $150 \%$ male, 50 $\%$ female) who are subscribed to "Islamic" and "Scientific marriage websites in Turkey are analyzed using qualitative content analysis. Gender display categories of Goffman (1987) and Kang (1997) are implemented together with shooting angle categories of Kress and van Leeuwen to analyze the visual content of marriage website users' profile pictures. Additionally, the self-presentation of users through their profile pictures are investigated with other categories (location, dressing / make up). The results reveal that the representation of gender in mainstream media share considerable similarities with the self-presentation of marriage websites users in Turkey and the profile pictures of "Islamic" and socalled "Scientific" marriage websites users reproduce the existing gender stereotypes in mainstream media.
\end{abstract}

keywords: marriage, digital media, self-presentation, gender stereotypes

Bu makaleye referans vermek için: Uğur Tanrı̈ver, H. ve Sunam A. (2017). Türkiye'deki Çevrimiçi Evlilik Siteleri: Medyanın Benlik Sunumuna Etkisinin Toplumsal Cinsiyet Odaklı Bir Analizi. Galatasaray Üniversitesi Illeti-ş-im Dergisi, 26, 9-38. DOI: 10.16878/gsuilet.324170. 


\section{Résumé}

\section{Les sites de mariage en Turquie: une analyse de l'influence des médias sur une présentation genrée de soi}

Dans cet article, les photos de profil de 1200 internautes (50\% d'hommes, $50 \%$ de femmes ) inscrits sur des sites de mariage "Islamiques" et "Scientifiques" en Turquie sont analysées à l'aide d'une analyse de contenu qualitative. Les catégories de la représentation du genre de Goffman (1987) et Kang (1997) sont mises en oeuvre avec les catégories d'angle de vue de Kress et Van Leeuwen pour analyser le contenu visuel des photos de profile des internautes de sites de mariage. Par ailleurs, l'auto-présentation des internautes par le biais de leurs photos de profil sont étudiés en reference à d'autres catégories (emplacement, habillage / maquillage). Les résultats révèlent que l'auto-présentation des usagers de sites de mariage en Turquie reproduisent en grande partie les mêmes representations de genre que dans les medias classiques, et que les photos de profil des internautes de sites de mariage "islamiques" et qui se consident comme "scientifiques" ne présentent pratiquement pas de differences majeures quant à la reproduction de ces stéréotypes.

mots-clés : mariage, médias numériques, la présentation de soi, les stéréotypes de genre

\section{Öz}

Bu çalışmada kendilerini "islami" ve "Bilimsel" olarak konumlayan iki çevrimiçi evlilik sitesine üye olan 1200 kullanıcının 1\% 50 erkek kullanıcı, \% 50 kadın kullanıcı) benlik sunumlarında kullandıkları fotoğrafları niteliksel içerik analizi ile incelenmiştir. Goffman'ın (1987) ve Kang'ın (1997) toplumsal cinsiyet temsillerini değerlendirme kategorileri ve Kress ve van Leeuwen'in fotoğrafın görsel analizindeki çekim açıları değerlendirmeleri aracılığı ile kullanıcıların siteye yükledikleri fotoğraflar incelenmiştir. Bunların yanı sıra, benlik sunumunda kullanılan fotoğraflardaki mekan ve kullanıcıların givim, makyaj tarzı da analiz edilmiştir. Kullanıcıların benlik sunumları ile ana akım medyadaki toplumsal cinsiyet temsili arasındaki ilişkiyi ortaya koyabilmek amacıyla batı medyasındaki ve Türkiye'de toplumsal cinsiyet temsillerine yer verilmiştir. Araştırma sonuçları, toplumsal cinsiyetin ana akım medyadaki temsili ile çevrimiçi evlilik sitelerindeki benlik sunumunda kullanılan fotoğrafların büyük ölçüde benzerlik gösterdiğini; hem "islami", hem de kendini "bilimsel" olarak tanımlayan evlilik sitelerine üye olan kullanıcıların medyada yer olan toplumsal cinsiyet stereotipilerini yeniden üreten profil fotoğraflarına benlik sunumlarında yer verdiklerini, bu konuda aralarında büyük farklar olmadığını göstermiştir.

anahtar kelimeler: evlilik, dijital medya, benlik sunumu, toplumsal cinsiyet stereotipileri 


\section{Giriş}

Insanlık, kadın ve erkeklerin, ilkel üreme dürtüsüne uygun olarak yeni kuşaklara can verme ve yetiştirmeleri için uygun ortamları yaratmış; tarihin her döneminde ve her coğrafi-kültürel ortamda bu amaca uygun olarak "aile" adı verilen toplumsal kurumu inşa etmiştir. Türün devamı sağlamanın yanı sıra, cinsel dürtülerin denetlenmesi yoluyla toplumsal düzenin korunma ve sürdürülme hedefi, aile kurumunun hala en genel geçer deyimiyle "toplumun temeli" olarak görülmesinin; özgün hukuksal düzenlemelerin ötesinde, kurucu metinler olan anayasalarda bile yer almasının en temel nedenidir.

Aile, kültürel değerler, gelenekler, dini inançlar ve hukuk sistemleri doğrultusunda farklı biçimlere sahip olmuş, bu biçimler, her çağda ve ortamda, toplumların genel yaşam koşulları ve ihtiyaçlarına göre değişiklik göstermiştir. Birçok toplumsal-kültürel olgu gibi aileyi ve onunla bağlantılı başka olguları (cinsellik, mülkiyet, siyasal ve ekonomik sistemler, vb.) modernlik veya daha yakın dönemlerde geç modernlik paradigmasından hareketle inceleyen çalışmalar, aynı zamanda da bu bakış açısından günümüz toplumlarını daha iyi anlamamızı sağlarlar.

Modernleşme sürecini görece geç yaşayan Türkiye'de aile yapıları, özellikle XX. yüzyılla birlikte dönüşüme uğramış; buna karşılık kurumsal olarak ailenin sahip olduğu önem ve itibar önemini yitirmemiş; hatta siyasal açıdan daha muhafazakar iktidarlar döneminde daha da artmıştır. Başlangıçta kadın sorunlarıyla ilgilenme amacıyla kurulan bir devlet bakanlığının adının 2011 yılında "Aile ve Sosyal Politikalar Bakanlığı"'na dönüştürülmesi bile bu durumun açık bir göstergesidir.

Aile kurma yolunda temel adım kadın ve erkeğin meşru biçimde birlikte yaşamalarıdır; bu meşruluk hukuksal olarak "nikah" yoluyla onaylanırken, toplumsal-kültürel olarak da "düğün" ve evlilik sürecinde yer alan çeşitli ritüeller ile desteklenir. TUiK'in 2016 verileri doğrultusunda (tuik.gov.tr, 2017) yılda 594 binin üzerinde çift evlendiği görülmekte ve bu evliliklerde düğ̈n ve yeni ev kurmanın ortalama maliyeti 50.000 TL'sına ulaşmaktadır. Bir başka deyişle evlilik, henüz başlangıcında 30 milyar liralık bir pazarı temsil ederek, ulusal ekonominin önemli bir "kalem"ini oluşturmaktadır.

Türkiye'deki evliliklerin büyük bir bölümü yakın döneme kadar "görücü" usulü, yani eşlerin birbirlerini yakından tanımadan, ailelerinin kararıyla evlenmesi biçiminde gerçekleşmiştir (Nauck \& Klaus, 2008, s. 295-296). Kentleşme ve sanayi toplumu modellerine kısmen uyum sağlama sonucu bu eğilimin değiştiği düşünülse de istatistik veriler değişimin görece olduğunun altını çizer. TUiK'in 2016 yılı Aile Yapısı Araştırması, Türkiye'de ilk evliliklerini yapanların toplamda \% 60'ının görücü usulü ile evlendiğini ortaya koymaktadır (tuik.gov.tr, 2017). Yaklaşık her 10 kişiden biri (\%12) kendi rızası olmaksızın görücü usulü evlendiğini 
belirtmekte; \% 48 oranında bir kitle ise görücü usulü olmakla birlikte eşleriyle tanışarak veya evliliğe rıza gösterdiklerini belirterek, en azından bu yönde bir değişimin varlığını işaret etmektedir.

Günümüzde kadın ve erkeklerin doğal ortamlarda tanışarak evlilik kararı alabilecekleri "karma toplumsallaşma" olanakları hâlâ çok kısıtlı, bazı kesimler için ise hiç mümkün değildir. Dolayısıyla bu olanaklara sahip olmayanlar açısından, evlenme amacıyla birisiyle tanışma olanaklarının yaratılması her iki cins için de önem arz etmektedir. Nitekim bire bir yüz yüze iletişimin yerini alan dolaylandırımış iletişim biçimi olarak çağımıza ve kültürümüze egemen olan medya, evlilik konusunda da yeni bir açlım oluşturmuştur. Popüler televizyon kanallarında yayınlanan evlilik programlarının varlığı ve yüksek izlenme oranları bu durumun somut göstergesidir.

Özellikle son 10 yılda yeni teknolojiler ve mobil iletişim olanaklarının giderek yaygınlaştığı Türkiye'de "evlilik pazarı" olarak adlandırabileceğimiz alan, bu mecraların zengin olanaklarına uyum göstermiş; çevrimiçi evlilik siteleri de kısa zamanda yüksek kullanıcı oranlarına erişmiştir.

Bu makalede bulgularını paylaştığımız araştırma, eş bulma amacıyla çevrimiçi evlilik sitelerine üye olan kadın ve erkeklerin potansiyel eşlerine kendilerini nasıl bir benlik sunumuyla tanıttıklarını, Goffman'ın "benlik sunumu" yaklaşımından (1987) hareketle incelemeyi amaçlamaktadır. Bu benlik sunumunun aile ve evilik açısından temel nitelikli bir paradigma olan toplumsal cinsiyete göre şekillenme biçimi ve ana akım medyada yer alarak kamusal "meşruluk" kazanan egemen cinsiyet stereotipilerinden etkilenme düzeyi araştırmanın sorunsalını oluşturmaktadır. Araştırmada, benlik sunumu biçimleri ve cinsiyet stereotipilerinin ortaya çıkarılmasında önemli bir öğe olan tematik fotoğraf analizi yöntemi kullanılmıştır.

\section{Dünyada ve Türkiye'de Çevrimiçi Arkadaşlık ve Evlilik Pazarı}

Çevrimiçi arkadaşlık' ve evlilik sitelerini kullanmak bugün dünyada oldukça yaygın olan bir sosyal pratiktir. (Bajos, Bozon 2008; Brym, Lenton 2001; Daneback 2006; Hogan vd. 2011; Madden, Lenhart 2006; Schulz vd. 2008). ${ }^{2}$ Pew Research Center'ın ABD'deki çevrimiçi arkadaşlık ve evlilik pratikleri ile ilgili 2016 raporu, ABD nüfusunun yüzde 15'inin tanışma ve eş bulma amacı ile bu gibi siteleri ve telefon uygulamalarını kullandığını; ciddi bir ilişki içinde ya da evli olan Amerikalı çiftlerin yüzde $5^{\prime}$ inin ise eşleri ile çevrimiçi tanışma/evlilik siteleri ve/ya uygulamaları aracılığı ile tanıştığını göstermektedir (Smith ve Anderson, 2016). ABD'de yapılan başka bir araştırma ise homoseksüel çiftlerin yüzde 41'inin ve

1 Dünya literatüründe "dating websites" olarak adı geçen siteler, Türkiye'de "arkadaşlık siteleri" olarak konumlandırılmaktadır. Bkz. https://www.siberalem.com/, www.istanbul.net

2 Daha fazla bilgi için; Bergström, M. (2011). Casual dating online. Sexual norms and practices on French heterosexual dating sites. Journal of Family Research. s. 319 
heteroseksüel çiftlerin yüzde 17'sinin çevrimiçi siteler ve uygulamalar aracılığı ile tanıştığını göstermektedir (Rosenfeld ve Thomas, 2010, s. 537). Çevrimiçi arkadaşlık ve evlilik sitelerinin popülerliklerinin artması ile birlikte, çevrimiçi arkadaşlık ve evlilik pazarının da giderek büyüdüğü (Cesar, 2016), sadece Avrupa'da (datingsitesreviews.com, 2017) ve ABD'de (Yoder, 2014) dokuz binin üzerinde çevrimiçi arkadaşlık ve evlilik sitesinin faaliyet gösterdiği bulgulanmıştır.

Dünyadaki çevrimiçi arkadaşlık ve evlilik sitelerinin ağırlıklı olarak ABD merkezli olan bu oyuncuları, tek bir merkezden, ulus aşırı bir düzlem olan sanal ağlar üzerinden, dünyanın farklı köşelerinde, farklı etnik kökene, dini inanışa sahip milyonlarca internet kullanıcına tanışma ve evlenme hizmetleri sunmaktadırlar. Lardellier, özellikle 2006 sonrasındaki dönemde çevrimiçi arkadaşlık ve evlilik pazarının farklı etnik, sosyokültürel ve dini gruplara göre bu şekilde ayrışmaya başlamasını, "pazarın ekonomik aktörleri tarafından çevrimiçi arkadaşlık ve evlilik pazarında endogaminin yürürlüğe sokulması" (Lardellier, 2015, s. 91) olarak yorumlamıştır. Pazarın büyümesini sağlayan etkenlerden biri olan bu girişimin, farklı geçmişlere sahip olan internet kullanıcılarını çevrimiçi düzlemde ayrıştırılmasına ve benzer sosyal çevrelerden gelen kişilerin buna yönelik olarak hazırlanan siteler aracılığı ile benzer öz geçmişe sahip kullanıcılarla tanışmasına yol açtığı söylenebilir.

Bu mecralara dair çalışmaların ve gözlemlerin ortaya çıkardığı işleyiş şemasına göre, çevrimiçi arkadaşlık ve evlenme sitelerine üye olmak için ilk adım erkek kullanıcılar için üyelik ücretini ödemekle başlar. Kadın kullanıcılardan genellikle üyelik ücreti alınmaz. Siteye üye olan kullanıcıların öncelikle kendilerini tanıtmaları ve sevgili/eş adayı ile ilgili beklentilerini site üzerinde belirtmeleri gerekir. Buna uygun olarak siteler üyelerine kendilerini tanıtmaları için çoktan seçmeli şıklar (yaş, meslek, etnik kimlik, din, fiziksel özellikler, medeni durum, çocuk sayısı, vb.), fotoğraflarını yüklemeleri için bir alan ve kendi sözleri ile benlik sunumlarını ve eş adayı beklentilerini aktarmaları için açık uçlu bir alan sunarlar. Kendileri ve eş / sevgili adaylarını tarif eden ve fotoğraflarını yükleyen kullanıcılar, bu adımları tamamladıktan sonra sitedeki filtreleme seçenekleri (yaş, boy, alışkanlıklar, meslek, din, vb.) aracılığı ile eş / sevgili kriterlerine göre adaylarını belirlerler. Tüm bu süreçleri tamamlayan kullanıcılar diğer kullanıcılarla iletişime geçebilirler. Çevrimiçi arkadaşlık ve evlilik siteleri kullanıcılarının iletişime geçmeleri için mesajlaşma, göz kırpma, hediye gönderme, ve benzeri seçenekler sağlarlar. Site üzerinden başlayan iletişim genellikle diğer medya araçları (facebook, skype, telefon, SMS, whatsup, vb.) ile bir süre devam eder. Bu süreçten sonra yüz yüze görüşmek isteyen kullanıcılar ilk buluşmalarını gerçekleştirirler.

Internet aracılığı ile sevgili ve/ya eş bulma pratikleri akademisyenlerin ve araştırmacıların da ilgisini çekmiş; son yıllarda çevrimiçi arkadaşlık ve evlilik pratikleri üzerine tüm dünyada geniş bir literatür oluşmaya başlamıştır. Bu alan üzerine çalışan akademisyenler çevrimiçi tanışma pratiklerinin geleneksel tanışma ve eş bulma pratiklerinden nasıl ayrıştığını, bu sitelerdeki kadın ve erkek 
kullanııların benlik sunumlarını nasıl gerçekleştirdiklerini, benlik sunumunda yer alan beyanların doğruluğunu ve toplumsal cinsiyet normları ile ilişkisini incelemişlerdir. Bunların yanı sıra, din, coğrafi yakınlık, yaş ve siteler üzerinden tanışan kullanıcılar arasındaki çevrimdışı ilişki pratikleri incelenen diğer alanlardır. ${ }^{3}$

2000 'li yılların ortasından itibaren evlilik ve arkadaşlık siteleri eğilimi Türkiye'de de görülmeye başlanmıştır. Günümüzde, Türkiye'deki evlilik siteleri kendilerini 'Íslami' ve 'Bilimsel / Ciddi' olarak tanımlayan evlilik siteleri olarak iki kutupta yer almaktadır. "Bilimsel / Ciddi" evlilik siteleri üyelerine "bilimsel" eşleştirme yöntemleri (pembepanjur.com/npp.php, 2017) kullanarak hizmet sunduklarını iddia ederler. İslami evlilik sitelerini bu sitelerden ayıran en önemli fark ise, sitelerin kendi hizmetlerini konumlandırmak için kullandıkları "íslami" söylemdir (gonuldensevenler.com/whygs, 2017). Bunun yanı sıra, bu iki site formatının, sitelerinde yer verdikleri üye profil formlarının içeriklerinin ve üyelerine sundukları eş arama kriterlerinin farklılıklar gösterdiği bulgulanmıştır. Bu siteler dışında farklı etnik gruplara, ideolojik duruşlara, mesleklere, vb. sahip kişilere yönelik irili ufaklı evlilik sitelerinin olduğu da gözlemlenmiştir. ${ }^{4}$

Türkiye'de evlilik siteleri oldukça yüksek bir kullanıcı sayısına sahiptir. Çevrimiçi evlilik siteleri arasında en çok üyeye sahip olduğunu iddia eden site ecift.com sitesidir ve 5 milyon üyesi vardır. Bu siteyi pembepanjur.com, gonuldensevenler.com ve nasipse.com çevrimiçi evlilik siteleri takip etmektedir. Pembe Panjur 4,130,000 üyeye sahip olduğunu beyan etmiştir. 2007 yılında kurulan ve Türkiye'deki çevrimiçi evlilik pazarının en eski oyuncularından biri olan Gönülden Sevenler sitesi ise 2014 yılı itibari ile 2 milyon üyesi olduğunu açıklamıştır, üye sayısının artmış olması beklenmektedir. Nasipse sitesinin ise 300 binin üzerinde üyesi bulunmaktadır. Evlilikmerkezi.com ise 2014 yılı itibari ile 100 bin civarında kullanıcıya sahiptir. Türkiye'deki evlilik siteleri dünyadaki ulus ötesi arkadaşık ve evlilik siteleri ile ilişkili siteler değil, yerli yatıımcılar tarafından kurulmuş, yerli ve yabancı yatıımlar alarak büyümesini sürdüren sitelerdir. ${ }^{5}$ Türkiye'nin en büyük İslami ve bilimsel evlilik sitelerinde kadın üyeler, diğer kadın üyeleri; erkek üyeler de diğer erkek üyeleri göremez.

Sürmekte olan doktora çalışmamız ${ }^{6}$ kapsamında yaptığımız geniş çaplı araştırma sonucunda elde edilen verilerin analizlerine göre çevrimiçi

3 Bu konunun farklı öğelerini inceleyen araştırmalara örnek olarak bkz; Whitty (2008), Hancock \& Toma (2008), Piela (2011), Wang (2011), Manning (2013), Ramirez, Sumner, Fleuriet vd. (2014) ve Uski \& Lampinen (2016)

$4 \mathrm{Bu}$ sitelere örnek olarak bervinizdivac.com, alevidunyası.com, doktorundunyası.com, annemevlenecek.com, solcuolsun.com siteleri gösterilebilir.

5 Bu sitelerin ekonomik olarak analizi de önemli veriler sunmakla birlikte, bu çalışmanın temel problematiğinin sınırlarını aştığından; ele alınmamıştır.

6 Sunam, A. (2017). Genç Müslümanlar Arasında Yeni Tanışma Ve Evlenme Biçimleri; Evlilik Sitelerinin Kullanımı. (Devam etmekte olan doktora tezi). Paris 1 Pantheon Sorbonne / Siyaset Bilimi Bölümü ve Galatasaray Üniversitesi / Medya ve Illetişim Çalışmaları (çift doktora). Bu tez çalışması, Prof. Dr. Hülya Uğur Tanrı̈ver ve Doç. Dr. Delphine Dulong'un danışmanlıklarında yürütülmektedir. 
arkadaşlık ve evlilik sitelerinin kullanıcılarının ağırlıklı olarak erkek üyeler olduğu, sitelerdeki ortalama yaşın otuz yaş üzeri olduğu ve İstanbul, Ankara ve İzmir gibi büyükşehirlerde yaşayan kullanıcı sayısının tüm site kullanıcılarının yaklaşık yarısını oluşturduğu görülmüştür. Çevrimiçi arkadaşlık ve evlilik sitelerini kullanan kişilerin eğitim düzeyi, Türkiye ortalamasının üzerindedir. Kadın ve erkek üyeler ağırlıklı olarak lise ve üniversite mezunudur.

Türkiye'de sınırlı sayıda da olsa çevrimiçi arkadaşlık ve evlilik siteleri üzerine yapılan akademik çalışmalar bulunmaktadır. Örneğin, Tütüncü, Göle'nin önerdiği kategorilerin (2002) ışığında, İslami evlilik sitelerini, İslam'ın kamusal alanda görünürlügünün arttığı ikinci dönemine ait bir ürün olarak ele alır. Yazar incelediği İslami evlilik sitelerinin Müslüman kadınların eş seçimlerinde özgürleşmelerine yol açabilecek araçlar olabileceğini söylemiş ama aynı zamanda "toplumsal cinsiyet eşitsizliğinin yeniden üretebileceği mekanlara" dönüşebilme potansiyelini taşıdıklarına da işaret etmiştir (Tütüncü, 2007, s. 304).

Kaymas ise, (2010) Lardellier'nin, çevrimiçi evlilik sitelerinin endogamiyi yaygınlaştıran araçlar olduğunu öne sürdüğü çalışmasındaki savına benzer bir şekilde, Türkiye'deki evlilik sitelerinin dini tutumlara göre ayrışmasını inceler. İslami evlilik sitelerinin, "İslamcı söylemin ve İslamcı seçkinlerin kamusal alanda edindiği yeni yerler" olduğunu öne süren Kaymas, bu sitelerin farklı gruplara kapalı siteler olduğunu ve "böylesi kapalı bir toplumsal ağ içerisinde ötekinin ve ötekinin değerlerinin" dışladığını iddia etmektedir.

Bunların yanı sıra, Türkiye'deki arkadaş ve evlilik sitelerini farklı perspektiflerden ele alan (Karaboğa, F., 2008; Özüstün, E. 2015; Yıldız, Ö. E., Deneçli, C., Deneçli, S., 2011) ve kullanıcılara yönelik anket gibi yöntemlerle yapılmış (Pala, 2015) veya dini içerikli sitelerin analizi kapsamında çevrimiçi evlilik sitelerinin kullanımını irdeleyen (Vardı, 2012) araştırmalar da vardır. Tüm bu çalışmalar, her ne kadar sayıları, özellikle de ABD veya Batı Avrupa'dakilere oranla sınırlı olsa da, Türkiye'de on milyonun üzerinde kullanıcıya sahip olduğu tahmin edilen çevrimiçi evlilik sitelerine yönelik akademik ilginin arttığını göstermek açısından önemlidir.

\section{Çevrimiçi Evlilik Sitelerinde Toplumsal Cinsiyet Temelli Benlik Sunumu ve Geleneksel Medyanın Etkisi}

Geliştirdiği "benlik sunumu" kavramıyla modern sosyolojinin yanı sıra, başta iletişim bilimleri olmak üzere birçok disipline temel katkılarda bulunan Goffman, sosyal etkileşim içindeki bireylerin içinde bulundukları ortamdaki diğer bireyleri etkileme motivasyonuna sahip olduklarını ve onların izlenimlerini kontrol etmeye çalıştıklarını söyler (Goffman, 1956, s. 8). Bullingham ve Vasconcelos, Goffman'ın bir "tiyatro sahnesine" benzettiği gündelik yaşamda, "aktörlerin" arzuladıkları izlenimi yaratabilmek adına, "sahne önü" diye tanımladığı sosyal ortamlarda bir "performans" sergilediklerini; kişinin izleyiciler tarafından 
görülmediği "sahne arkası"nda ise bir performansa gerek duymadıklarını belirtirler (Bullingham \& Vasconcelos 2013, s. 1). Bir başka deyişle ise, benlik sunumu "sosyal etkileşimlerde kişinin arzuladığı izlenimi yaratmak amacı ile benliğini paketlemesi ve kurgulaması"dır (Toma \& Hancock, 2010, s. 336).

Çevrimiçi evlilik siteleri, günümüz toplumsal ilişkileri düşünüldüğünde "sahne önü"ne mükemmel bir örnek oluşturmaktadır. Karşı cinsle duygusal bir ilişki kurmanın ötesinde evlilik gibi uzun süreli (olması umut edilen) bir birlikteliğin ilk adımını atma durumundaki kişilerin hayatlarını geçirecekleri eş adaylarına kendilerini ideal ve "beğenilecek" biçimde sunmaları beklenir. Bu medyanın özgünlüğü kullanıcılara, kendilerine ait kişisel bilgilerden fotoğraf kullanımına kadar birçok "kimlik" öğesini seçme, ayıklama ve düzenleme olanağı verir (Walther, 1996). Böylelikle kişiler bu sitelerde bir anlamda "kurgusal" bir benlik sunarlar. Tanışma ve evlilik sitelerinin çevrimiçi olma özellikleri de bu durumu pekiştirir. Nitekim kimi araştırmalar, bu sitelerde fotoğraflarını paylaşan kullanıcıların kendilerini "çevrimdışı görüntülerinden daha kusursuz bir şekilde yansıtabilmek" amacını güttüklerini ve bu amaçla "görsel işaretleri stratejik bir şekilde manipüle ettiklerini" (Ellison, Heino ve Gibbs, 2006, s. 415-441); örneğin çevrimiçi tanışma sitelerini kullanan üyelerin "daha ince ve daha çekici göründüklerini varsaydıkları" ve kimi zaman bu amaçla manipüle ettikleri fotoğrafları çevrimiçi sitelerde paylaştıklarını göstermektedir (Whitty; 2008, s. 1707-1723).

Cinsiyet kişilerin benliklerinin, kimliklerinin temel öğelerinden birini oluşturur. En geniş anlamıyla kültürel (toplumsal, siyasal, tarihsel) bir kurgu olarak toplumsal cinsiyet, tanımı gereği içinde yaşanan toplumun, ait olunan biyolojik cinsiyetten talep ettiği veya ona uygun gördüğü varsayılan davranış kalıpları, sosyal iletişim biçimleri, hatta düşünce ve duygularını benimseme, temsil etme ve yeniden üretme amacıyla oluşan bir yapıntıdır. Ve gerek iletişim bilimleri, gerek toplumsal cinsiyet çalışmaları alanında yapılan araştırmalar, toplumsal cinsiyet rollerinin içselleştirilmesi ve yeniden üretilmesinde aile ve yakın çevre gibi birincil toplumsal grupların yanı sıra medyanın da, sunduğu temsiller aracıı̆ğıla, belirleyici olduğunu ortaya çıkarmıştır.

Kişilerin benlik sunumlarında toplumsal cinsiyet çok değerli bir paradigma oluşturur ve bu sunumu kurgulamada, medyada yaygın olarak aktarılan toplumsal cinsiyet temsilleri belirleyici bir özelliğe sahiptir. Örneğin, Facebook veya MySpace gibi ortamlar üzerine yapılan çalışmalarda, erkek kullanıcıların benlik sunumlarında kendilerini "aktif ve eğlenmeyi seven" bireyler olarak tanıtma amacı güderken, kadın kullanıcıların ise "çekici bir görüntü" yansıtmayı tercih ettiği gözlemlenmiş (Strano'dan aktaran Zheng, Yuan, Chang, vd., 2016, s. 892893) veya bu araştırmalar "siteye kadınlar tarafından yüklenen fotoğrafların yüzde 20 'sinde kadınların açık ya da oldukça açık kıyafetler giydiğine" işaret etmişlerdir (Hall, West, Joshua, vd., 2012). Söz konusu fotoğrafların daha çekici olma kriterleri sorgulandığında, toplumsal-kültürel olarak ortak kabul gören rol modellerin ya da egemen güzellik, çekicilik, vb. kalıplarının irdelenme gereği ortaya çıkar. 
Benlik sunumunun toplumsal cinsiyet normlarından etkilenmesi, arkadaşlık ve evlilik siteleri açısından daha da önemli bir olgudur. Zira "karşı cins"le iletişim kurma amacındaki kullanıcıların kendi cins kimliklerine dair ipuçları vermesi bu iletişim ve ileride kurulacak ilişkinin yapıtaşını oluşturacaktır. Kadınlar ve erkekler potansiyel eşlerine kendilerini birer erkek veya kadın olarak en "çekici" biçimde sunmayı amaçlarken, aynı zamanda bu sunumda kuracakları birliktelik açısından önemli olan başka kimliklere dair de ipuçları verirler.

Çevrimiçi benlik sunumu üzerine yapılan araştırmalar da, medyadaki kadın ve erkek temsillerinin, bu mecraları kullanan üyelerin benlik sunumlarını ve fotoğraf kullanım pratiklerini etkilediğini işaret etmektedir.

\section{Anaakım Medyada Toplumsal Cinsiyet Temsilleri}

1960'ların sonundaki feminizmin ikinci dalgası ile beraber kadınların medyadaki temsil biçimleri üzerine yapılan sistematik çalışmalar hız kazanmaya başlamış; gazetelerden, televizyon içeriklerine; kadınlara "özgü" olduğu varsayılan pembe dizilerden, aşk romanlarına kadar birçok alanda farklı coğrafyalarda değerli çalışmalar yapılmıştır. 2000'lere doğru "toplumsal cinsiyet" kavramının gelişimi ve sosyal bilimlerde başlı başına bir paradigma oluşturmasıyla birlikte temsil sorunsalı kadınlarla sınırlı kalmayıp, erkekleri ve LGBTi bireyleri de kapsayarak genişlemiş, "erkeklik çalışmaları" ve "queer çalışmalar" biçiminde farklı disiplinleri ortaya çıkarmışlardır. ${ }^{7}$

İlkdönemyapılan çalışmalarda, medyada kadınların geleneksel stereotipilere göre, yani çoğunlukla ev ve özel alanla sınırlı olarak, eş-anne modeline göre veya erkeklerin "haz nesnesi" olarak fiziksel özellikleri, egemen güzellik kalıpları doğrultusunda ön plana çıkartılarak temsil edildikleri bulgulanmıştır. Öte yandan, medyanın sunduğu ideal kadın imgeleri gibi, erkek imgeleri de sorgulanırken, özellikle televizyon araştırmalarında, incelenen metinlerin eklektik yapılarının temsilleri çeşitlendirdiği de son dönemlerde belirlenen bir olgudur. İşlevselciliğe veya kullanımlar ve doyumlar kuramlarına 8 yakın duran bazı yazarlar, izleyicilerin bu temsil biçimlerinden "kendilerine uygun bulduklarını ödünç alabileceklerini" söyler (Gauntlett, 2008, s. 287-288).

Tüketim pratiklerinin kimliklerimizi şekillendirmesini değerlendiren feminist medya teorisyenleri (Killborne, 1999; Berberick, 2010) ise medyada yaşanan değişimlere rağmen, bugünün tüketim toplumunda da, medyanın kadınlara yönelik baskısının sürdüğünü söylemişlerdir.

7 Değindiğimiz tüm bu alanlarda farklı ülkelerde çok zengin bir literatür oluştuğundan, burada özel bir kaynak belirtmemeyi tercih ediyoruz. Araştırmacılar geniş literatür içinden kendi sorunsalları doğrultusunda uygun kaynaklara başvurabilirler.

8 illetişim kuramlarının topluca bir sunumu için bkz. Mattelart ve Mattelart (1995) 
"Feminist medya teorisyenleri, feminizm sayesinde kadınların bunaltıcı kadın rollerinden kurtulduklarını ama kadınları tüketici ve tüketim toplumunun işçisi olmaya zorlayan "kadınsı görüntü" baskısından kurtulamadıklarını iddia etmişlerdir." (Malik, 2014, s. 89)

Medyadaki ve özellikle reklamlardaki süregelen "kadınsı görüntü" ve "ideal kadın" kavramları üzerine yapılan çalışmalar, medyada yer alan kadınların beden dillerine bakıldığında, "erkeklerin beden dilinden farklı olarak kadınların genellikle pasif ve kolay incelenebilir" bir şekilde yansıtıldıklarını (Killbourne, 2010) göstermiştir. Bu alanda çalışılan diğer bir konu ise batı medyasında yansıtılan "güzellik idealleri" kavramıdır. Uzmanlar medyada yer alan güzellik ideallerinin, "cinsiyetçi" ve "gerçek-dışı" (Berberick, 2010, s. 2) olduklarına işaret ederler. Fotoşop ve benzeri tekniklerle "inceltilen", "pürüzsüzleştirilen", "kırışıklıklarından arındırılan" modeller aracılığı ile yansıtılan ulaşılması imkansız "güzellik idealleri" medyada yaygın bir şekilde paylaşılmaktadır.

Kadınların farklı medyalarda temsil biçimleri üzerine Türkiye'de de çok sayıda çalışma vardır. Dört mecra (gazete, radyo, televizyon ve internet haber siteleri) üzerine MEDiz (Kadınların Medya İzleme Grubu) tarafından yapılan çalışmanın (Uğur Tanrı̈̈ver, vd. 2007) yanı sıra, tek tek farklı mecra veya içerik biçimleri üzerine de değerli bir literatür oluşmuştur. ${ }^{9}$

Ana akım Türk medyasında kadınlar genelde "cinsel nesne / haz nesnesi", "melodramatik öğe", "magazin malzemesi" ya da haberleri görselleştirmek için "araç / konu mankeni" olarak yer almaktadır (Uğur Tanrı̈ver, 2008, s. 123). Egemen sosyal temsiller açısından bir diğer önemli mecra olan reklamlar değerlendirildiğinde ise, bu metinlerin dönemin yaygın değerlerini ve zaman içinde değişen cinsiyet rollerini yansıtacak şekilde kurgulandığını ve 80'li yıllardan itibaren geleneksel kadın rollerinin yanı sıra, kadınların "kariyer odaklı", "rahat", "sağlığına önem veren", "özgürlükçü" rollerde de temsil edilmeye başlandığı görülmektedir (Çık, 2017, s. 97).

Medyada kadın temsillerinin, genel söylemde ciddi bir dönüşüm olmasa da, çeşitlendiği açıktır. Nitekim, İslam'ın ikinci dönemi ile birlikte, Müslüman kimliklerin de medyadaki görünürlüğü giderek artmıştır ve günümüzde başörtülü kadın temsilleri sadece muhafazakar medyada değil, ana akım medyada da yer almaya ve çeşitlenmeye başlamıştır. Örneğin, İslami moda dergilerine bakıldığında; kadına atfedilen geleneksel roller (annelik, eş) dışında çalışan kadının temsiline de yer verildiği görülmüştür. Bir diğer bulgu ise "kadınsı görüntü" yaratmak amacıyla kullanılan "model pozları ve makyajın" zaman zaman dini kaygıların önüne geçmesidir" (Meşe, 2015).

9 Sınırlarımızı aşmamak adına burada özel bir kaynak belirtmemeyi tercih ediyoruz. Araştırmacılar geniş literatür içinden kendi sorunsalları doğrultusunda uygun kaynaklara başvurabilirler. 


\section{Toplumsal Cinsiyet ve İslami Kimlik}

Bireylerin sahip oldukları kimlikler arasında toplumsal cinsiyet kadar önemli bir başka kimlik de dini kimliktir. Dini kimlik başlı başına bir belirleyen olmasının ötesinde toplumsal cinsiyet algısını da şekillendirir ve bu kimlikle iç içe geçer. İslam dininin toplumsal cinsiyet ile etkileşimi uzun süre klasik "modernlik" paradigması ekseninde incelenmiştir. 1980'li yıllarla birlikte genelde din sosyolojisi ve toplumsal cinsiyet çalışmalarının gelişimi doğrultusunda bu etkileşim yeniden ve farklı yaklaşımlarla ele alınmaya başlanmış; 2000'lerden itibaren "íslami Feminizm"in bir siyasal hareket ve toplumsal cinsiyet çalışmalarının önemli bir alt alanı olarak ortaya çıkmasıyla daha da önemli çalışmalar yapılagelmiştir.

Göle, Türkiye'de başörtülü, eğitimli, kentli kadınlar üzerine yaptığı çalışmasında İslamcı hareket içinde yer alan türbanlı kadınların kamusal alanda görünürlük kazanması ve erkeklerle birlikte kentsel, siyasi ve eğitime ait alanları paylaşmaya başlaması ile birlikte modern kent mekanlarında yaşanan bu durumun hem geleneksel cinsiyet rolleri açısından, hem de batı modernizminin tanımladığı cinsiyet rolleri açısından "muğlaklık, belirsizlik ve gerilim yarattığını" ifade eder. Göle'nin bulgularına göre, yeni İslamcı aktörler, "kolektif" siyasal kimlikleri ve "bireysel" yaşam stratejileri etrafında kadın ve erkek arasındaki süregelen ilişkiyi dönüştürmekte; Batı modernizmine meydan okuyarak, moderniteyi kendi deneyimleri ile birlikte yeniden tanımlamaktadırlar (Göle, 1993).

Bir başka deyişle sosyolojik gözlemler ve araştırmalar, toplumsal cinsiyet kimlikleri ile İslami kimliklerin süreç içinde dönüşüme uğradıklarını; durağan bir İslam yaklaşımının tersine, bu inancı paylaşan topluluklar açısından dinamik, çağın gerekleri ve koşullarıyla ilintili yeni yaşam pratiklerinin geliştirildiğini ortaya koyarlar. Böylelikle, uzun süre klasik modernleşme kuramları doğrultusunda Türk modernitesini simgelemiş olan kalıplaşmış “kadın” kimliği de ${ }^{10}$ yerini daha çoğul ve farklı kimliklere bırakmaya başlar.

Bu değişim ya da Göle'nin deyimiyle modernitenin, deneyimlerin ışığında yeniden tanımlanması gündelik yaşam pratiklerinde birçok alanda kendini gösterir. Bu alanlardan biri de yeni teknolojilerin kullanımı ve etkileşimli medya ile kurulan ilişkilerdir. Tüm diğer kimlik grupları gibi, kendilerini dindar Müslüman olarak tanımlayan kişi ve topluluklar da, bu kimlikleriyle sosyal ağlarda yer almakta; paylaşım sitelerini kullanmakta ve bizim çalışmamızdaki örnekte görüldüğü üzere İslami yaşam tarzlarına uygun eş adayları bulmak amacıyla çevrimiçi sitelerde yer almaktadırlar.

Müslüman ve dindar kimliklerini ön plana çıkaranların sosyal paylaşım sitelerindeki benlik sunumlarının, hem ana akım medyada sunulan toplumsal

$10 \mathrm{Bu}$ "simge kadın" tiplemesinin farklı mecralardaki temsili birçok akademik araştırmaya konu oluşturmuştur. Görsel temsil açısından sinema alanında önemli bir çalışma için bkz. Toy Par, A. (2005) "Les effets de la modernisation sur la société turque des années 60 à travers les films réalistes", Galatasaray Üniversitesi Illeti-ş-im Dergisi, Sayı: 3, s. 65-80. 
cinsiyet stereotipilerinden, hem de bunların dini inanç ve pratiklerle eklemlenmesinden etkilendiği son dönemlerde yapılan çalışmalarda ortaya çıkmıștır. Örneğin, Aslanoğlu, çalıșmasında, Göle'nin otuz yıl önceki analizinde yer verdiği "modern" ve "mahrem" arasındaki ilişkinin muğlaklığının ve belirsizliğinin halen devam ettiğini gösterir ve muhafazakar genç kuşağın "bireysel" yaşam stratejilerinin yanı sıra, bu stratejilerin kolektif İslamcı kimliği aracılığı ile yorumlanma biçimlerine yer verir. Instagram kullanıcısı olan "genç, muhafazakar kadınlar"ı odak alan çalışmada yazar, "mahrem" olarak tanımlanan alanın (yakın yüz fotoğrafları, eve ve ev eşyalarına ait fotoğraflar, ev içinde gerçekleşen pratikler, nişanlı, eş, vb.) paylaşılan fotoğraflar aracılığı ile çevrimiçi kamusal alanda görünür olmasının zaman zaman kullanıcıların bireysel pratiklerini sorgulamalarına yol açtığını söyler. Muhafazakar genç kadınlar, bir yandan "popülerlik", "takipçi sayısı" gibi değerleri önemserken, bazı zamanlarda da paylaştıkları fotoğrafın "uygunsuz" olduğuna kanaat getirerek bu fotoğrafları "vicdanlarının" sesini dinleyerek sildiklerini dile getirmişlerdir (Aslanoğlu, 2016). Öte yandan, bu gibi benlik sunumunu düzenleme ve denetleme pratiklerinin, "toplumsal gözetim" mekanizmaları (Marwick, 2012, s. 379) ile ilişkili olduğunu da söylemek mümkündür.

Bu bulgular bize sosyal paylaşım ağları veya çevrimiçi sitelerde kullanıııların dini muhafazakar kimliklerini ön plana çıkartmak amacıyla farklı benlik sunumları yapacakları varsayımına götürecektir. Devam etmekte olan doktora çalışmamız kapsamında yaptığımız geniş çaplı araştırmanın bazı bulguları da, toplumsal cinsiyetin ve muhafazakarlığın benlik sunumuna etkisine yönelik varsayımlarımızı sınamamızı olanaklı kılmıştır.

\section{Çevrimiçi Evlilik Sitelerinde Kullanılan Fotoğrafların Çözümlemesi}

Bu çalışma kapsamında, biri kendisini "İslami" diğeri ise "bilimsel"11 olarak tanımlayan iki evlilik sitesinin kadın ver erkek üyelerine ait fotoğraflar "çevrimiçi ortamda katıımlı gözlem yapma yollarından biri olan 'pusucu' konumunda"12 (Binark, 2015, s.140) kalınarak incelenmiştir.

Her iki site üye sayısının çokluğu ve sitelerde yer alan fotoğrafların görüntülenebilir olması ölçütlerine göre seçilmiş; 4 gün süreyle, en yoğun kullanım saatleri olan 20.00 - 24.00 arasında, sitede fotoğrafı bulunan ve çevrimiçi olan 300 kadın ve 300 erkeğin fotoğrafları ara yüzey kayıtlama yöntemi ile temin edilerek toplamda 1200 fotoğraf üzerinde çalışılmışır. Bu makaleye temel oluşturan çözümlemede cinsiyet dışındaki klasik demografik değişkenler dikkate alınmamıştır. Ancak bir fikir vermesi açısından, her iki sitenin kullanıcı profilinin de

11 Bu nitelemeler, deyim yerindeyse sitelerin kendi kurumsal "benlik sunum"larıdır. Ayrıca "bilimsel" sıfatı hem sitenin verdiği hizmet açısından abartııı bulunduğundan, hem de yanlış anlamalara yol açabileceğinden biz örneklememizde kullandığımız ölçüt doğrultusunda bu iki siteyi "İslami / muhafazakar" ve "liberal" olarak adlandıracağız.

12 Daha fazla bilgi için; Binark, M. (Der.). (2015). Yeni Medya Çalışmalarında Araştırma Yöntem ve Teknikleri. ìstanbul: Ayrıntı Yayınları, sy. 71 ve sy. 140 incelenebilir. 
büyük kentlerde yaşayan, ortalama 34 yaşında kadın ve erkeklerden oluştuğunu hatırlatmak yararlı olacaktır.

Kozinets, netnografik 13 araştırmalara yönelik etik önerileri arasında çevrimiçi ortamların özel ya da kamusal olup olmamasının dikkatle incelenmesine; araştırmacının kendi kimliğini, amaçve ilgilerini topluluktaki üyelere açıklamasınave kullanıcıların gizliliğini / anonimliğini koruyacak şekilde hareket etmesi gerektiğine yer verir (Binark, 2015, s. 72). Çevrimiçi ortamların özel / kamusal alan olarak değerlendirilmesi konusunda Papacharissi, bu ortamların kamuya açıklık / kapalııı seviyelerine; üyelik kriterlerine; üye profillerine erişim koşullarına ve üyelerin arama motorlarında görüntülenebilir olup, olmamasına bakılmasını önermektedir (Papacharissi, 2009, s. 206-209). Çevrimiçi evlilik sitelerini bu bağlamda ele aldığımızda, üye profillerinin arama motorlarında yer almadığını görürüz. Üyelik koşulları kadın ve erkek kullanıcılar için farklıık göstermektedir. Tüm üyeler karşı cinse ait profil sayfalarını görüntüleyebilirler ancak kadın kullanıcılarla iletişime geçmek isteyen erkek kullanıcılar için ücret ödeyerek özel üye olma zorunluluğu vardır (bkz:gonuldensevenler.com/pay/gold, 2017). Bunlara ek olarak kullanıcıların siteye üye olma amaçları da değerlendirildiğinde, bu sitelerin tamamen kamuya açık siteler olduğunu söylemek mümkün değildir. Kozinets'in araştırma etiği ile ilgili diğer önerileri de bu kapsamda değerlendirilmiştir. Pusucu konumunda yer almasına rağmen araştırmacı, sitede bulunma amacını ve araştırmacı kimliğini sitelerde yer alan profil sayfalarında belirtmiş; site sahipleri ile iletişime geçerek sitede gözlemlerde bulunacağını ve kullanıcıların benlik sunumlarına ait verileri araştırma etiği kriterlerini göz önünde tutarak inceleyeceğini bildirmiştir. ${ }^{14}$ Bu kapsamda, yine profil fotoğrafları incelenen 1200 kullanıcının anonimliğini ve gizliliğini koruma amacıyla kullanıcılara ait diğer bilgilere araştırmada yer verilmemiştir.

Son olarak, çevrimiçi evlilik sitelerinde kullanılan fotoğrafların çözümlemesinde kullanılan kriterlerin görsel karşııklarını aktarabilmek amacıyla, İslami ve liberal evlilik sitelerine üye olan 12 üyeye ait fotoğraf, illüstratör ve fotoşop programları kullanılarak yeniden çizilmiştir. Bu temsili çizimler hazırlanırken araştırma etiği, site kullanıcılarının gizlilik hakları ve sitelerin telif hakları gözetilerek, kullanıcılara ait özellikler (yüz hatları, saç /sakal, aksesuarlar/ giyim, renk kullanımı, arka plan, vb.) değiştirilmiş ve yukarıda bahsedilen kriterleri aktarabilmek için pozları korunmuştur.

13 "Antropolojinin geleneksel olarak yüzyüze yürüttüğü niteliksel ve yorumlamalı araştırma yönteminin bilgisayar dolayımlı iletişimler ile oluşturulmuş çevrimiçi kültürlere ve topluluklara uyarlamasıdır" (Jupp'tan aktaran Kozinets içinde Binark, 2015: 69-70).

14 Bu araştırma kapsamında, Pembe Panjur evlilik sitesi yöneticisi ile iki kere yüz yüze derinlemesine mülakat yöntemi kullanılarak görüşme gerçekleştirilmiş; Pembe Panjur kullanıcılarına ait sosyodemografik çıkarımlar site yöneticisi tarafından araştırmacıya iletilen meta verinin analizi sayesinde tespit edilmiştir. Gönülden Sevenler evlilik sitesi yöneticisi ile bir kez telefonda görüşülmüş ve araştırma hakkında kendisi bilgilendirilmiştir. Pembe Panjur sitesinden farklı olarak, Gönülden Sevenler site yöneticisi araştırma kapsamında yüz yüze mülakat yapmayı tercih etmediğini araştırmacıya bildirmiştir. Bu siteye ait sosyo-demografik çıkarımlar ise ara yüzey kayıtlama yöntemi ile temin edilen verilerin analizi sayesinde gerçekleştirilmiştir. 
Kişinin kendisini tanıtma amacıyla kullandığı fotoğrafların toplumsal cinsiyet rolleri bağlamında benlik sunumuyla bağıntısını ortaya çıkarmak için tematik içerik çözümlemesi gerçekleştirilmiştir; genelde görüntü çözümlemede kullanılan kamera açısı, mekan kullanımı gibi ölçütlerin yanı sıra, Goffman (1987) ve Kang'ın (1997) toplumsal cinsiyet temsillerini değerlendirme kategorileri ile beraber toplumsal cinsiyet rollerini imleyen diğer tematik öğeler de bu çalışmada dikkate alınmıştır. Burada yapılan çözümleme de bu farklı değişken gruplarını birlikte değerlendirmeyi amaçlamaktadır.

\section{Mekanın cinsiyeti: Özel alan/kamu alanı eksenindeki kimlikler}

Toplumsal cinsiyet çalışmaları, hatta bunların öncülü olan kadın çalışmaları, toplumsal yaşamda kadın ve erkeklerin eşit hak ve özgürlüklerden yararlanmıyor olmasını temel karşıtlıklar doğrultusunda kurgulanan cins kimlikleriyle açıklarlar. Bu doğrultuda kadınlar, başta ev olmak üzere özel alanda konumlandırılırken, kamu alanı erkeklere ait olarak görülür.

Evlilik sitelerini kullanan kadın ve erkek kullanıcıların kendilerini sundukları fotoğraflarda, kullanıcıların içinde yer aldıkları mekanların tematik analizi sonucunda elde ettiğimiz bulgular, bu kalıplaşmış yaklaşımın çevrimiçi evlilik sitelerini kullanan üyelerin büyük bir kısmı tarafından benimsediğine işaret etmektedir.

Tablo 1. Gönülden Sevenler İslami Evlilik Sitesi-Fotoğraflarda Mekan Kullanımı

\begin{tabular}{|l|l|l|l|l|}
\hline Cinsiyet & İç Mekan & Dış Mekan & Araba & Toplam \\
\hline Kadın \% & 63 & 34 & 3 & 100 \\
\hline Erkek \% & 51 & 42 & 7 & 100 \\
\hline
\end{tabular}

Tablo 2. Pembe Panjur Evlilik Sitesi-Fotoğraflarda Mekan Kullanımı

\begin{tabular}{|l|l|l|l|l|}
\hline Cinsiyet & İç Mekan & Dış Mekan & Araba & Toplam \\
\hline Kadın \% & 69 & 27 & 4 & 100 \\
\hline Erkek \% & 44 & 45 & 11 & 100 \\
\hline
\end{tabular}

Incelenen çevrimiçi evlilik sitelerinde kadın kullanıcıların erkek kullanıcılara oranla daha sıklıkla iç mekanda çekilmiş fotoğrafları kullanmayı tercih ettikleri gözlemlenmiştir. Özellikle, Pembe Panjur sitesinde, kadın kullanıcıların (\% 69) erkek kullanıcılara (\% 44) oranla iç mekanda çektikleri / çektirdikleri fotoğrafları paylaşmayı tercih ettikleri görülmüştür. Gönülden Sevenler sitesinde de, kadın 
kullanıcıların (\% 63) iç mekanda çekilmiş fotoğrafları, erkek kullanıcılara (\% 51) oranla daha sıklıkla kullandıkları bulgulanmıştır. Statü göstergesi olarak değerlendirilebilecek araba içinde/kullanan pozlar ise erkek kullanıcıların daha fazla tercih ettiği bir pratiktir.

Bunun yanı sıra, fotoğraflarda kullanılan "iç mekan" kategorileri incelendiğinde, Gönülden Sevenler çevrimiçi İslami evlilik sitesi üyelerine ait fotoğraflarda "duvar ve cam önü" fotoğrafları, kadınların ve erkeklerin en sık kullandıkları fotoğraflardır. Erkek kullanıcılar ikinci sırada "iş yeri ya da ofis" olarak tanımlanabilecek yerlerde poz verdikleri fotoğrafları (\% 36) sıklıkla kullanırken, kadın kullanıcılar bir "evde" çekildiği anlaşılan fotoğrafları tercih etmektedir. İşyerinde çekilen fotoğrafı kullanan İslami evlilik sitesi üyesi kadınların oranı ihmal edilecek kadar düşüktür (\% 3).

Tablo 3. Gönülden Sevenler İslami Evlilik Sitesi-Fotoğraflarda İç Mekan Kategorileri

\begin{tabular}{|l|l|l|l|l|l|}
\hline Cinsiyet & Duvar / Cam Önü & Ev & Kafe / Restoran & Ofis / İşyeri & Toplam \\
\hline Kadın \% & 49 & 38 & 10 & 3 & 100 \\
\hline Erkek \% & 40 & 16 & 9 & 36 & 100 \\
\hline
\end{tabular}

Tablo 4. Pembe Panjur Evlilik Sitesi-Fotoğraflarda İç Mekan Kategorileri

\begin{tabular}{|l|l|l|l|l|l|}
\hline Cinsiyet & Duvar / Cam Önü & Ev & Kafe / Restoran & Ofis / İşyeri & Toplam \\
\hline Kadın \% & 47 & 33 & 11 & 9 & 100 \\
\hline Erkek \% & 36 & 17 & 18 & 29 & 100 \\
\hline
\end{tabular}

Pembe Panjur sitesi kullanıcılarının iç mekanda çekilen fotoğrafları incelendiğinde bu siteye üye olan kadınlar arasında da "evde" çekilen fotoğrafların sıklıkla kullanıldığını görebiliriz. Ancak, her ne kadar, "ofis ya da iş yerinde" çektiği fotoğrafı profil fotoğrafı olarak paylaşan erkek kullanıcıların oranı (\% 29), kadınlarınkinin yaklaşık üç katı olsa da, bu liberal evlilik sitesinin kadın kullanıcıları \% 9 oranında ofis veya işyeri fotoğrafı paylaşmaktadır. Bu oran İslami evlilik sitesindeki kadınların 3 katıdır. Pembe Panjur kullanıcıları, Gönülden Sevenler kullanıcılarından farklı olarak "barda" çekilen ya da çektikleri fotoğrafları da, profil fotoğrafı olarak kullanmakta; böylelikle benlik sunumlarında yaşam tarzına dair de çağrışım yaratma eğiliminde olduklarını göstermektedirler. 
Resim 1: Araba, A. Görüş

Resim 2: Dik Duruș, Göz h.

Resim 3: İşyeri
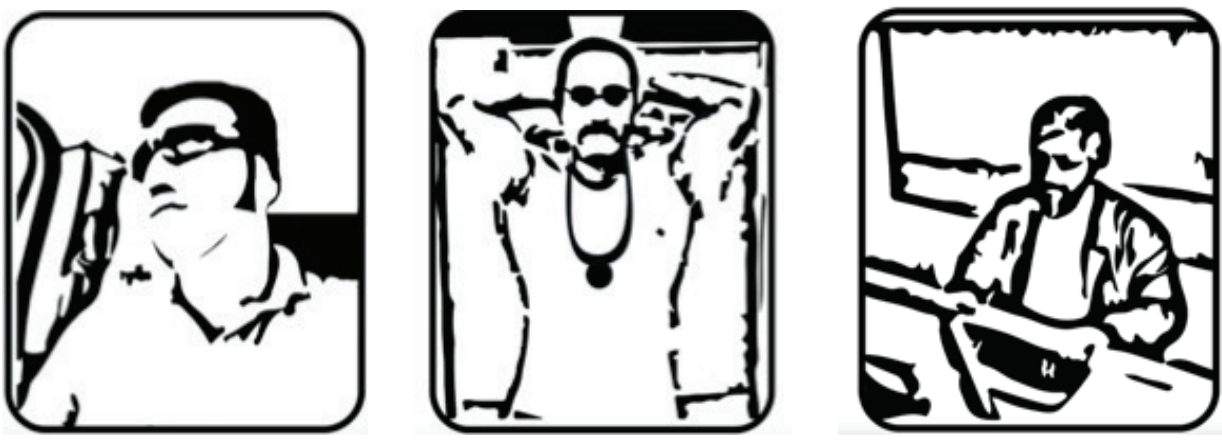

Resim 4: Dik Duruş, Göz h.

Resim 5: Araba

Resim 6: İşyeri
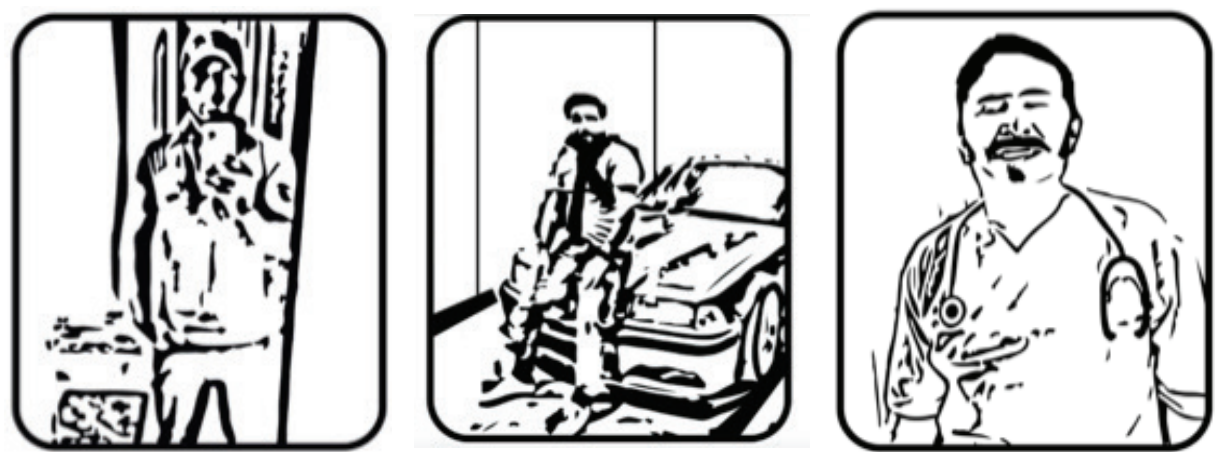

Dışarıda çekilmiş fotoğrafların ne tür mekanlarda konumlandığı ayrıntılı olarak incelendiğinde, İslami evlilik sitesi üyesi hem kadın, hem de erkek kullanıcıların "yeşil alan, boğaz, orman, deniz kenarı, vb." gibi manzaralı yerleri tercih ettikleri görülmektedir. Pembe Panjur kullanıcıları, Gönülden Sevenler kullanıcılarından farklı olarak "plajda" çekilen ya da çektikleri fotoğrafları da, profil fotoğrafı olarak kullanmaktadır. Liberal evlilik sitesi üyesi erkeklerin, İslami site üyelerine göre daha fazla "kafe /restoran" gibi mekanları tercih etmeleri de, tıpkı plaj veya bar gibi yaşam tarzı, eğlenme biçimi konusunda gizli mesaj verme olarak yorumlanabilir.

Tablo 5. Gönülden Sevenler İslami Evlilik Sitesi-Fotoğraflarda Dış Mekan Kategorileri

\begin{tabular}{|l|l|l|l|l|l|}
\hline Cinsiyet & $\begin{array}{l}\text { Yeşil Alan, } \\
\text { Boğaz, vb. }\end{array}$ & Kafe / Restoran & $\begin{array}{l}\text { Tarihi Mekan/ } \\
\text { Şehir Manzarası }\end{array}$ & Diğer & Toplam \\
\hline Kadın \% & 55 & 19 & 18 & 8 & 100 \\
\hline Erkek \% & 62 & 10 & 22 & 6 & 100 \\
\hline
\end{tabular}


Tablo 6. Pembe Panjur Evlilik Sitesi-Fotoğraflarda Dış Mekan Kategorileri

\begin{tabular}{|l|l|l|l|l|l|}
\hline Cinsiyet & $\begin{array}{l}\text { Yeşil Alan, } \\
\text { Boğaz, vb. }\end{array}$ & Kafe / Restoran & $\begin{array}{l}\text { Tarihi Mekan/ } \\
\text { Şehir Manzarası }\end{array}$ & Diğer * & Toplam \\
\hline Kadın \% & 43 & 15 & 17 & 25 & 100 \\
\hline Erkek \% & 39 & 24 & 19 & 17 & 100 \\
\hline
\end{tabular}

* Pembe Panjur sitesi kullanıcılarından, Gönülden Sevenler sitesi kullanıcılardan farklı olarak, plajda çekilen fotoğraflarına yer verdikleri görülmüştür. Bu kategori diğer başlığı altında ele alınmıştır.

\section{Toplumsal cinsiyetin göstergesi : Duruş}

Reklam fotoğrafları üzerine çalışan Goffman'ın (1987) geliştirdiği ve Kang'ın (1987) bunlara ek olarak önerdiği kategoriler; evlilik sitelerine üye kadınların ve erkeklerin benlik sunumlarında kullandıkları fotoğraflardaki duruşlarının toplumsal cinsiyet kurgusunu anlamada bizim de başvurduğumuz bir çerçeve oluşturmuştur. ${ }^{15}$

"Kadınsı dokunuş" olarak adlandırılan duruş biçimi; adından anlaşılacağı üzere daha çok kadınlarda görülen ve nesneleri tutmak, kavramak yerine, yüzeylerine çok az temas ederek dokunması, yüzeyini okşaması gibi bir dokunma biçimini işaret eder. (Goffmann, 1987, s. 29-31). Özellikle reklam fotoğraflarında bu "kadınsı" dokunuşun nesneler kadar, fotoğrafı çekilen kadınların kendilerine de yöneldiği; yüz, saç, göğüs, karın, omuz, dudak gibi bölgelere dokunan kadın duruşlarının çokça kullanıldığı görülür.

Tablo 7. Çevrimiçi Evlilik Siteleri-Toplumsal Cinsiyet Temsilleri Kategorileri

\begin{tabular}{|l|l|l|l|}
\hline & \multicolumn{3}{|l|}{ Kadınsı Dokunuş / Kendine dokunma (yüz, saç, göğüs, dudak, karın, omuz) } \\
\hline Cinsiyet & $\begin{array}{l}\text { Gönülden Sevenler İslami Evlilik } \\
\text { Sitesi }\end{array}$ & Cinsiyet & Pembe Panjur Evlilik Sitesi \\
\hline Kadın \% & 16 & Kadın \% & 20 \\
\hline
\end{tabular}

Incelenen her iki evlilik sitesinde de kadınların kullandıkları fotoğraflarda kendi bedenlerinin farklı alanlarına yönelik bu "kadınsı" dokunuşa çok fazla yer vermedikleri görülmektedir. Daha liberal olarak niteleyebileceğimiz Pembe Panjur'da bu oran \% 20; İslami site Gönülden Sevenler'de ise \% 16'dır. Hem

15 Çevrimiçi evlilik sitelerinde fotoğraflarını paylaşan üyelerin tek başlarına oldukları fotoğrafları paylaşmayı tercih ettikleri görülmüştür. Bu nedenden ötürü, Goffman'ın reklamlarda kadın ve erkeklerin birlikte bulundukları fotoğrafları incelemek için kullandığı "Nisbi Büyüklük" ve "Görev Hiyerarşisi" (Goffman, 1987, s. 32-34) kategorileri kullanılmayacaktır. Goffman'ın kategorilerine ek olarak, kadınların oturma pozisyonunda görüntüledikleri fotoğraflarda değerlendirilmiştir. 
aradaki bu farkı, hem de aslında her iki sitede de oranın görece düşüklüğünü bu duruşun aslında cinsellik çağrıştırıyor olması; kadınların bu şekilde sunumunun medya analizlerinde sıkça yer verilen "cinsel nesne" konumunu pekiştiriyor olmasıyla açıklamak mümkündür. Evlilik amaçlı sitelerde kadınlar eş adaylarına kendilerini cinselliklerini ön plana çıkararak sunmayı tercih etmemektedirler.

Toplumsal ortamdan geri durma ya da çekilme olarak adlandıılan kategori, kadınların fotoğraflarda, toplumsal ortamdan psikolojik bir şekilde geri çekildiklerini gösterecek şekilde ya da duygularını (pişmanlık, korku, utanma, gülme) kontrol edemez, ne yapacağını bilmeyen bir şekilde gösterildiklerini durumları işaret eder. Ağızlarını elleri ile kapatan ya da bacaklarını geriye doğru çekerek içe kapanan kadın pozları bunlara örnek olarak verilebilir. Bunların yanı sıra, bakışını kameradan çeken, uzaklara bakan pozların kontrolü başkalarına bırakma anlamına geldiğini söyleyen Goffman, bu gibi pozları da bu kategori içinde değerlendirir (Goffman, 1987, s. 46-47).

Tablo 8. Çevrimiçi Evlilik Siteleri-Toplumsal Cinsiyet Temsilleri Kategorileri

\begin{tabular}{|l|l|l|l|}
\hline & \multicolumn{4}{|l|}{ Toplumsal Ortamdan Geri Durma / Çekilme } \\
\hline Cinsiyet & $\begin{array}{l}\text { Gönülden Sevenler İslami Eviliik } \\
\text { Sitesi }\end{array}$ & Cinsiyet & Pembe Panjur Evlilik Sitesi \\
\hline Kadın \% & 17 & Kadın \% & 17 \\
\hline
\end{tabular}

Her iki evlilik sitesindeki kullanıcı fotoğrafları incelendiğinde, yaklaşık her altı kadından birinin "toplumsal ortamdan geri durma / çekilme" kategorisine denk düşen fotoğrafları profil sunumlarında kullandıkları, özellikle de bakışlarını kameradan çeken, uzaklara bakan fotoğraflar aracılığıyla böyle bir duruş sergiledikleri görülmektedir.

Goffman, kadınların reklam fotoğraflarındaki özgün duruş biçimlerinden bazılarını "edilgen / itaatkar konum" başlığı altında tanımlamıştır. Başı ve bedeni dik tutmak, hiyerarşik olarak üstün konuma işaret ederken, Goffman reklamlarda kadının edilgen ya da itaatkar duruşunu imleyecek biçimde, başları ya da bedenleri eğik şekilde temsil edildiğini ve bunun itaat etmek ve/ya ödün vermek olarak okunması gerektiğini söyler (Goffman, 1987, s. 46-47). Hem İslami hem de daha liberal olarak tanımladığımız bu sitelere üye olan, her iki kadından birinin itaatkar konumu imleyen bir biçimde, başları / boyunları eğik fotoğraflarını benlik sunumlarında kullandıkları görülmüştür. 
Resim 7: K. Dokunuş,

Dengesiz

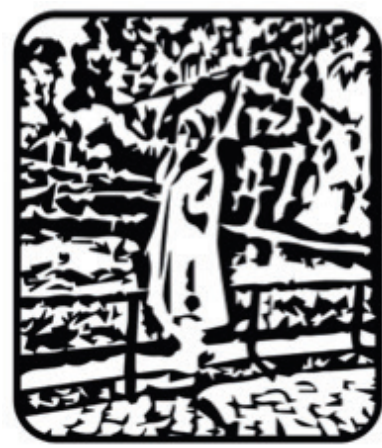

Resim 10: K. Dokunuş, Dengesiz

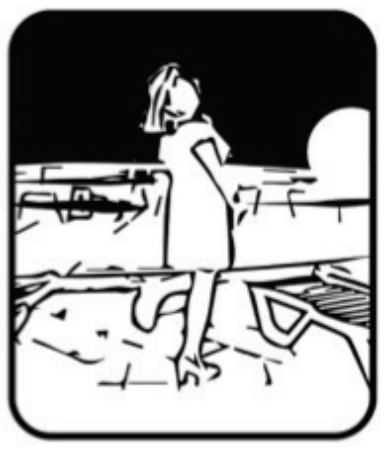

Resim 8: K.Dokunuş, Eğik baş, Ü. Görüş

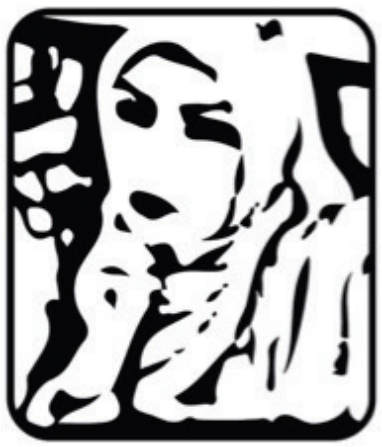

Resim 11: Eğik baş, Ü. Görüş

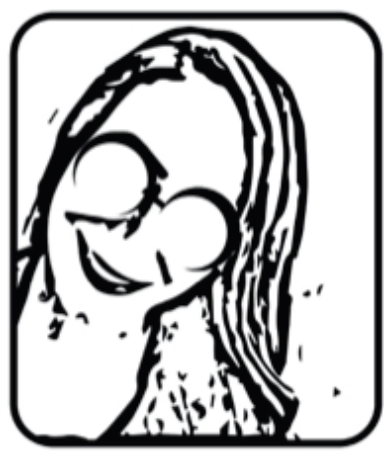

Resim 9: Ü. Görüş

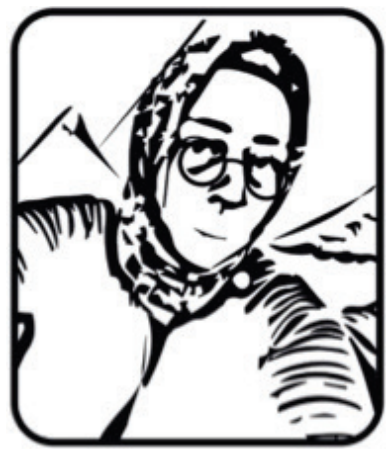

Resim 12: Ü. Görüş

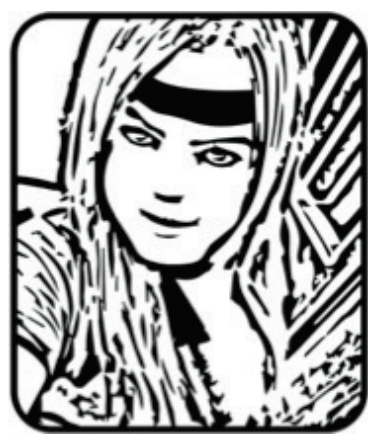

Buna karşılık erkek kullanıcıların ayakları yere basan şekilde, dik konumda oldukları ve tüm bedenlerinin görüldüğü fotoğrafları sıklıkla kullandıkları, kadınların oturur pozisyonda oldukları ve bedenlerinin tam olarak görünmediği fotoğrafları tercih ettikleri bulgulanmıştır.

Goffman, reklamlarda kadınların ve çocukların sıklıkla yerde, kanepede, yatakta uzanmış pozlarına yer verildiğine dikkat çeker. Yazarın, "serilip yatmak" olarak tanımladığı ve "cinsel ilişkiye hazır olma" fikrini çağrıştırdığını söylediği bu kategori de "edilgen / itaatkar konum"un altında yer alan duruşlardan biridir (Goffman, 1987, s. 40-43). Cinselliği ön plana çıkartan "serilip yatma" fotoğraflarının, Türkiye' deki çevrimiçi evlilik sitelerinde çok sık karşımıza çıkmadığı görülmüştür. Başın geriye atıldığı duruş da "edilgen / itaatkar konum" altında yer alır. Bu duruşun da bu sitelerde sıklıkla görüldüğünü söylemek mümkün değildir. 
Tablo 9. Çevrimiçi Evlilik Siteleri-Toplumsal Cinsiyet Temsilleri Kategorileri

\begin{tabular}{|c|c|c|c|c|c|c|c|}
\hline \multicolumn{7}{|c|}{ Gönülden Sevenler İslami Evlilik Sitesi-Edilgen / İtaatkar duruş * } & \multirow[b]{2}{*}{ Toplam } \\
\hline Cinsiyet & $\begin{array}{l}\text { Serilip } \\
\text { Yatmak }\end{array}$ & $\begin{array}{l}\text { Bir Ayağı } \\
\text { Kaldırmak } \\
\text { ya da } \\
\text { Kıvırmak }\end{array}$ & $\begin{array}{l}\text { Başın Eğik } \\
\text { Olduğu } \\
\text { Duruş }\end{array}$ & $\begin{array}{l}\text { Bedenin } \\
\text { Eğik } \\
\text { Olduğu } \\
\text { Duruş }\end{array}$ & $\begin{array}{l}\text { Başı } \\
\text { Geriye } \\
\text { Atmak }\end{array}$ & $\begin{array}{l}\text { Oturma } \\
\text { Pozisyonu }\end{array}$ & \\
\hline Kadın \% & 6 & 5 & 45 & 8 & 3 & 33 & 100 \\
\hline \multicolumn{7}{|c|}{ Pembe Panjur-Evlilik Sitesi Edilgen / İtaatkar duruş * } & \\
\hline Cinsiyet & $\begin{array}{l}\text { Serilip } \\
\text { Yatmak }\end{array}$ & $\begin{array}{l}\text { Bir Ayağı } \\
\text { Kaldırmak } \\
\text { ya da } \\
\text { Kıvırmak }\end{array}$ & $\begin{array}{l}\text { Başın Eğik } \\
\text { Olduğu } \\
\text { Duruş }\end{array}$ & $\begin{array}{l}\text { Bedenin } \\
\text { Eğik } \\
\text { Olduğu } \\
\text { Duruş }\end{array}$ & $\begin{array}{l}\text { Başı } \\
\text { Geriye } \\
\text { Atmak }\end{array}$ & $\begin{array}{l}\text { Oturma } \\
\text { Pozisyonu }\end{array}$ & Toplam \\
\hline Kadın \% & 5 & 5 & 45 & 11 & 2 & 32 & 100 \\
\hline
\end{tabular}

* Bazı kadın kullanıcı fotoğraflarının birden fazla kategoriye ait özellikleri içerdikleri bulgulanmıştır.

Bunların yanı sıra, reklamlarda kadınların erkeklere oranla daha fazla gülümseyen pozları olması ve gülümsemenin, karşısındakini "onama", "kabul etme" anlamları taşıdığı da duruş ve toplumsal cinsiyet ilişkisi açısından önemli bir saptamadır (Goffman, 1987, s. 48-49). Kullanıcıların yüz ifadeleri incelendiğinde, her iki sitedeki kadınların büyük bir çoğunluğunun güler yüzlü oldukları fotoğrafları paylaştıkları ortaya çıkmıştır. Öte yandan, erkeklerin kadınlara oranla daha az gülümseyen konumda olmaları, eril duruşun "ciddiyet" ile bağdaştııılığı bir kültürü işaret ederken; İslami sitede hem kadın hem de erkeklerin liberal sitedekilere oranla daha düşük oranlarda gülümseyen fotoğraf kullanmalarının da belli bir dindarlık anlayışına göre Müslümanlara yakıştırılan "vakar" ile ilintili olduğu düşünülmektedir.

Tablo 10. Çevrimiçi Evlilik Siteleri-Üye Profil Fotoğraflarında Yüz Ifadesi / Gülümseme

\begin{tabular}{|l|l|l|l|}
\hline Cinsiyet & $\begin{array}{l}\text { Gönülden Sevenler } \\
\text { İslami Evililik Sitesi }\end{array}$ & Cinsiyet & Pembe Panjur Evlilik Sitesi \\
\hline Kadın \% & 59 & Kadın \% & 80 \\
\hline Erkek \% & 30 & Erkek \% & 45 \\
\hline
\end{tabular}

\section{Öz-çekim Kamera Açıları}

Goffman ve Kahn'ın değerlendirme kategorilerinin yanı sıra, çevrimiçi evlilik sitelerinde yapılan netnografik gözlemler sonucu kadın ve erkeklerin öz-çekim fotoğraflarında kullandıkları görüş açısının da fotoğraflardaki benlik sunumlarını 
etkilediği görülmüştür. Fotoğraf teorisi ve fotoğrafların yapısal çözümlemesi üzerine çalışan akademisyenler de, kamera hareketinin ve bakış açısının fotoğrafın söylem çözümlemesindeki önemine işaret ederler.

“Temsil edilen birey 'üstten görüş' ile görüntüleniyor ise, 'izleyenin izlenen katılımcı(lar) üzerinde otoritesi olduğu', izleyenin izlenenden daha güçlü olduğu söylenebilir (...) Eğer izlenen katılımcı 'alttan görüş' ilse görüntüleniyorsa, 'izlenen katııımcının izleyen üzerinde otoritesi olduğu' söylenebilir (...) Eğer görüntüleme göz hizasında gerçekleşiyorsa, burada 'izlenen ve izleyen arasında sembolik bir eşitlik ilişkisi' olduğu varsayılır." (Van Leeuwen \& Jewitt, 2004, s. 3)

Bu değerlendirmenin ışığında, erkek ve kadın evlilik sitesi kullanıcılarının özçekim fotoğraflarında kullandıkları kamera açıları arasındaki farklılıkları göstermek amacıyla, "üstten görüş", "alttan görüş" ve "göz hizası" kamera açlları da fotoğrafları değerlendirmek için birer kriter olarak kullanılacaktır. Bu kategorilerin yanı sıra çevrimiçi evlilik sitelerinin gözlemleri sırasında, kullanıcıların aynadaki yansımalarını profil fotoğraflarında paylaştıkları görülmüştür. Bu nedenle bu kategori de eklenmiştir.

Tablo 11. Çevrimiçi Evlilik Siteleri-Üye Profil Fotoğraflarında Çekim Türü

\begin{tabular}{|l|l|l|l|l|l|l|l|}
\hline \multicolumn{6}{|l|}{ Gönülden Sevenler İslami Evlilik Sitesi } & \multicolumn{4}{l|}{ Pembe Panjur Evlilik Sitesi } \\
\hline Cinsiyet & Özçekim & Normal & Toplam & Cinsiyet & Özçekim & Normal & Toplam \\
\hline Kadın \% & 48 & 52 & 100 & Kadın \% & 62 & 38 & 100 \\
\hline Erkek \% & 26 & 74 & 100 & Erkek \% & 33 & 67 & 100 \\
\hline
\end{tabular}

Her iki sitede kadınların, erkeklerden daha fazla öz-çekim fotoğrafı kullandıkları görülmüştür. İslami evlilik sitesi üyesi erkek kullanıcıların ise sadece dörtte biri öz-çekimlerini sitede profil fotoğrafı olarak paylaşmayı tercih etmiştir. Her iki sitede de, kadınların kendilerini aşağı konumda gösterecek şekilde "üstten görüş" diye adlandırılan yukarıdan çekim tekniğini, erkeklerden daha fazla tercih ettikleri saptanmıştır. Bu çekimler detaylı incelendiğinde öz-çekim kullanan kadınların yaklaşık yüzde 41 'inin "üstten görüş" diye adlandırılan yukarıdan çekimi tercih ettikleri, buna karşılık erkek kullanıcıların \% 58'inin kendilerini "alttan görüş" ile çekilen fotoğrafları kullandıkları bulgulanmıştır. Pembe Panjur evlilik sitesi kullanıcıların profil fotoğrafları incelediğinde, her 5 kadından 3 'ünün öz-çekimlerini profil fotoğrafı olarak kullandıkları görülmektedir. Pembe Panjur sitesine üye olan kadın kullanıcıların da çoğunlukla (\% 56) kendilerini aşağıda gösterecek şekilde, cep telefonu ile "üstten görüş" ile yukarıdan çekimi tercih ettiklerini, erkek kullanıcıların ise "göz hizasından" çekim yapmayı tercih ettiklerini söyleyebiliriz. 
Tablo 12. Çevrimiçi Evlilik Siteleri-Öz-Çekim Görüş Açıları

\begin{tabular}{|l|l|l|l|l|l|}
\hline \multicolumn{6}{|l|}{ Gönülden Sevenler İslami Evlilik Sitesi } \\
\hline Cinsiyet & Ayna & Üstten görüş & Alttan görüş & Göz hizası & Toplam \\
\hline Kadın \% & 6 & 41 & 17 & 36 & 100 \\
\hline Erkek \% & 4 & 22 & 58 & 16 & 100 \\
\hline Pembe Panjur Evlilik Sitesi & \multicolumn{5}{|l|}{} \\
\hline Cinsiyet & Ayna & Üstten görüş & Alttan görüş & Göz hizası & Toplam \\
\hline Kadın \% & 3 & 56 & 19 & 22 & 100 \\
\hline Erkek \% & 8 & 32 & 18 & 37 & 100 \\
\hline
\end{tabular}

İslam'ın geleneksel ve genel olarak kabul gören yorumuna göre, "mahrem olanın korunması" amacıyla, "kadının bedensel ve davranışsal olarak mütevazı bir tutum belirlemesi"nin beklendiğini (Göle, 1997, s. 22); bunun yanı sıra, hem ana akım medyada, hem de İslami kadın dergilerinde sunulan kadın temsillerinde yansıtılan, "ideal kadın" ve "kadınsı görünüş" kalıplarının kadınların benlik sunumlarını yapmalarında etkili olduğunu belirtmiştik. Tüm bu nedenlerden ötürü, çevrimiçi evlilik sitelerini kullanan kadınlar arasında sembolik bir ayrışma unsuru olarak da okunabilecek, örtünme, başörtüsü, mütevazı fizik (makyajlı -makyajsız / resmi-şık-seksi-gündelik /spor) gibi başlıca kriterleri ele alarak fotoğrafların nicel dağılımına da bu araştırma kapsamında yer vermeyi uygun gördük.

Bu kriterlerin altında, İslami evlilik sitesine üye olan kadınların (\% 40), liberal evlilik sitesine üye olan kadınlardan (\%12), daha fazla oranda başörtülü fotoğraf kullanmayı tercih ettiği saptanmıştır. Her iki sitede de, başörtüsü kullansın, kullanmasın kadın üyelerin, medyanın makbul olarak sunduğu "kadınsı görünüm"e uygun biçimde, çoğunlukla makyajlı fotoğraflarını paylaştıkları görülmüştür. İslami evlilik sitesinde başörtülü kullanıcıların \% 23'ü makyajsız fotoğraf paylaşmayı tercih ederken, başörtüsüz üyelerin sadece \% 14'ü makyajsı fotoğraf kullanmayı tercih etmiştir. Pembe Panjur sitesi kullanıcıların ise sadece \% 9'u makyajsız fotoğraf kullanmıştır.

Çevrimiçi evlilik sitelerindeki fotoğraflardaki giyim tarzı incelendiğinde en çok gündelik / spor kıyafetlerin tercih edildiği görülmüştür. Erkekler, kadınlara oranla resmi giyimli (takım elbise, kravat) oldukları fotoğrafları sitede paylaşmayı tercih etmişlerdir. Bu bulgu, erkeklerin ofis ve iş yerinde oldukları fotoğrafları paylaşma pratiklerine paralel olarak, toplumsal konumlarının göstergesi olarak okunabilir. Pembe Panjur sitesine üye olan kadınların, İslami evlilik sitesi kullanıcılarına göre daha fazla seksi giyimli fotoğraflarını paylaştıkları görülmüştür. Bunun yanı sıra, İslami evlilik siteleri kadın kullanıcıların \% 9,3'ü güneş gözlüğü kullandıkları 
fotoğrafları tercih etmiştir. Erkek kullanıcılarda da güneş gözlüğü kullanımının yaygın olduğu görülmüştür. Pembe Panjur sitesinin erkek kullanıcılarının \% 18,6'sının güneş gözlüğü kullandıkları fotoğrafları paylaştıkları tespit edilmiştir. Sürmekte olan doktora çalışmamız kapsamında kullanıcılarla yaptığımız yarı yapılandırılmış mülakatlar, bazı kullanıcıların çevrimiçi evlilik sitelerinde kimliklerini gizleme arzusunda olduklarını ortaya çıkarmıştır. Bu nedenle kullanıcıların benlik sunumlarında görülen güneş gözlügü kullanımının bu arzuya işaret ettiği düşünülmektedir.

Tablo 13. Çevrimiçi Evlilik Siteleri-Üye Profil Fotoğraflarında Giyim ${ }^{16}$

\begin{tabular}{|c|c|c|c|c|c|c|c|}
\hline \multicolumn{8}{|c|}{ Gönülden Sevenler İslami Evlilik Sitesi } \\
\hline Cinsiyet & gündelik / spor & resmi & şık / abiye & seksi & üniforma & N/A & Toplam \\
\hline Kadın \% & 63 & 6 & 11 & 1 & - & 19 & 100 \\
\hline Erkek \% & 78 & 18 & - & - & 4 & - & 100 \\
\hline \multicolumn{8}{|c|}{ Pembe Panjur Evlilik Sitesi } \\
\hline Cinsiyet & gündelik / spor & resmi & şık / abiye & seksi & üniforma & N/A & Toplam \\
\hline Kadın \% & 73 & 7 & 4 & 10 & - & 6 & 100 \\
\hline Erkek \% & 77 & 19 & - & 1 & 2 & 1 & 100 \\
\hline
\end{tabular}

\section{Sonuç yerine}

Stuart Hall, "temsilin, anlam üretimi sürecinde ve üretilen bu anlamın belli bir kültüre mensup üyeler arasındaki mübadelesinde temel ve vazgeçilemez bir rolü olduğunu" söylemiş (Hall, 1997, s. 15) ve "temsil edilme biçimlerimizin bizim kendimizi sunma şekillerimizi etkilediğini" öne sürmüştür (Hall'dan aktaran Varol, 2014, s. 314). Kadınların medyadaki temsil biçimlerinde 1970'lerden beri çeşitli değişimler yaşansa da, her tür medyada yer bulan "kadınsı görüntü" baskısının devam ettiği görülmektedir.

Makalenin ilk bölümlerinde de yer verildiği gibi ana akım Türk medyasındaki toplumsal cinsiyet temsilleri üzerine yapılan birçok araştırma (Gencel Bek, Binark, 2000; Alankuş, 2009: Uğur Tanrı̈ver, 2008) kadın ve erkek temsillerinin eşitsiz dağılımına ve bu temsillerin ayrımcı stereotipileri yeniden ürettiğine dikkat çekmiştir. Goffman'ın kategorileri doğrultusunda kadın fotoğraflarına bakıldığında, duruş, beden ve yüzün konumu, giyim ve makyajın yanı sıra,

$16 \mathrm{Bu}$ araştırma kapsamında kot / spor pantolon, spor ayakkabı, penye / koton bluz, tişört gibi kıyafetlerle poz vermeyi tercih eden kullanıcılar "gündelik / spor" giyim kategorisinde; takım elbise, kumaş pantolon, tayyör ve benzeri giysileri tercih eden kullanıcılar "resmi" giyim kategorisinde; vücut hatlarını gösterecek şekilde mini etek ya da dekolte giyim tarzını tercih eden kullanıcılar "seksi" giyim kategorisinde; özel toplantılarda ya da gecelerde giyilen, gösterişli kıyafetler "şık / abiye" kategorisinde ve kullanıcıların mesleklerine işaret eden doktor, hemşire, asker ve benzeri mesleklere ait kıyafetler "üniforma" kategorisinde değerlendirilmiştir. 
fotoğrafların çekiminde tercih edilen görüş açısı, kadınların kendilerini itaatkar, savunmasız, karşısındakini onaylayan; karşısındakinden (erkekten) aşağı konumda yer alan ve mütevazı biçimde sundukları; çoğunlukla kadınlara uygun görülen "ev" ortamında, yani özel alanda yer aldıkları; eş adayları üzerinde "hafif meşrep" izlenimi bırakmamak için cinsel çağrışım yapan poz ve duruşlardan kaçındıkları görülmektedir. Buna karşılık, erkekle kendilerini kontrollü, güçlü, meslek sahibi, karşısındakine tepeden bakan, üstün ve Türkiye geneli açısından prestij göstergesi olan araba sahibi olarak sunarlar. İslami ve bilimsel evlilik sitelerindeki profil fotoğrafları üzerine yapılan bu araştırma ve analiz sonucunda, kadın ve erkek üyelerin benlik sunumlarında kullandıkları fotoğrafların ana akım medyada yer alan toplumsal cinsiyet temsillerini yansıttığı ve medyadaki toplumsal cinsiyet temsillerindeki eşitsizliği yeniden ürettiğini söyleyebiliriz. Kendilerini ana akım medyada kabul gören toplumsal temsil biçimlerine benzer biçimde sunan kadın ve erkeklerin, bu doğrultuda kurgulanmış profil fotoğraflarını eş adaylarını etkilemek amaçlı kullandıkları düşünülmektedir. Doksan sonrasında çekilen bazı reklamlar (Çık, 2017) ve son dönem Türk sinemasına ait bazı örnekler düşünüldüğünde (Elmacı, 2011, s. 201), evlilik sitelerindeki benlik sunumunda kullanılan fotoğraflar üzerinden okunacak toplumsal cinsiyet temsillerinin, bahsedilen reklamlar ve filmlere göre daha da geleneksel bir temsil biçimine işaret ettiğini de iddia edebiliriz.

Bu çalışma sırasında ortaya çıkan diğer bir önemli bulgu ise farklı simgesel sermayelere sahip olan İslami ve bilimsel evlilik sitelerinin üyelerinin benlik sunumlarındaki benzerlik olmuştur. Kaymas, İslami Evlilik sitelerinin "ötekini ve ötekinin değerlerini" tamamen dışladığını iddia etmiştir. Çalışmamııın bulguları, çevrimiçi evlilik sitelerine üye olan kadınların başörtüsü kullanma oranları arasındaki farklılığa rağmen, genelde medyada süregelen toplumsal cinsiyet temsillerini benzer biçimde ve oranda içselleştirdiklerini göstermektedir. Aynı zamanda, İslami ve liberal evlilik sitesi üyelerinin benlik sunumlarında kullandıkları fotoğraflar, Goffman'ın çalışmasındaki temsil ritüelleri kriterleri açısından incelendiğinde de, iki site kullanıcıları arasında önemli ölçüde benzerlikler olduğu görülmüştür. Batı literatüründe yer alan, sosyal medya sitelerindeki toplumsal cinsiyet temsilleri araştırmalarındaki (Döring, Reif, Poeschl, 2016, s. 961; Kapidzic \& Martins, 2015, s. 279) bulgulardan farklı olarak, Kang'ın "beden teşhiri" kategorisinin ise Türkiye'deki evlilik sitelerindeki fotoğraflar açısından uygun bir kategori olmadığı, sadece sınırlı sayıda kadın ve erkek kullanııının profillerinde açık / çok açık giyimli fotoğraf kullandığı görülmüştür. Aynı şekilde cinselliğe hazır durumda olmayı ifade eden "serilip" yatma kategorisine ait fotoğraflara da incelenen sitelerde pek rastlanmamıştır.

Şüphesiz fotoğraf üzerinde gerçekleştirilen tematik içerik çözümlemesine dayanan bu çalışmanın bulgularını, söz konusu fotoğrafların sahipleri nezdinde yapılacak bir saha çalışmasıyla zenginleştirmek; benlik sunumlarında kullandıkları fotoğraflara uyguladıkları düzenlemeler ve fotoğraflarının çevrimdışı görüntüleri ile ne ölçüde benzeştiği / ayrıştığını saptayabilmek de çok yararlı olacaktır. Bu 
alanda gelecekte yapılacak çalışmalar, benlik sunumu fotoğraflarındaki stratejik manipülasyonları anlamamı ve manipülasyonların, medyadaki toplumsal cinsiyet temsilleri ile ilişkisini görmemiz açısından faydalı olacaktır. Yine, bu araştırmanın sınılları dahilinde, evlilik sitelerini kullanan üyelerin sadece profil fotoğrafları incelenmiştir. Profil fotoğraflarının seçilme sebebi, üyelerin sayfasına tıklandığında, profil formunda yer alan ve sitede arama yapıldığında karşımızda çıkan ilk üye fotoğrafları olmalarıdır. Sitelerde yapılan çevrimiçi etnografik gözlem, kullanıcıların profil fotoğraflarının, kimi zaman siteye yükledikleri diğer fotoğraflarından farkıııklar gösterebildiğini ortaya çıkarmıştır. Gelecekte profil fotoğrafları ile kullanıcıların evlilik sitelerinde yer verdikleri diğer fotoğrafların karşılaştırılması da, üyelerin benlik sunumlarını anlamak açısından yararlı sonuçlar çıkaracaktır. Son olarak, evlilik siteleri, kullanıcıların eş adayı bulmaları amacı ile tasarlanmış sitelerdir. Türkiye'deki arkadaşlık siteleri ve uygulamaları üzerine yapılacak ileriki bir çalışma, kısa süreli birliktelikler yaşamak isteyen veya cinsel partner arayan kişilerin benlik sunumlarını anlamamızı ve evlilik sitelerindeki benlik sunumlarından nası farkılıştıklarını daha net görmemizi sağlayacaktır.

\section{Kaynakça}

Aile Yapısı Araştırması, 2016 (18 Ocak 2017), Erişim 15 Şubat 2017, http://www. tuik.gov.tr/PreHaberBultenleri.do?id=21869

Alankuş, S. (2007). Kadın Odaklı Habercilik, BIA, IPS Iletişim Vakfı Yayınları, İstanbul Aslanoğlu, H. N. (2016). Muhafazakar Genç Kuşağın Instagram Profilleri: Mahremiyet, Moda ve Ahlakilik Illişkisi Üzerine Bir Değerlendirme. http:// www.ilem.org.tr/blog/wp-content/uploads/2016/09/Muhafazak\% C3\%A2rGen\%C3\%A7-Ku\%C5\%9Fa\%C4\%9F\%C4\%B1n-Instagram-Profilleri.pdf

Bauman, Z. (2011). Akışkan Aşk Insan Ilişkilerinin Kırılganlı̆ına Dair, Çev. Işık Ergüden, Versus Kitap, İstanbul.

Beck, U. \& Beck, E. (2012). Aşkın Normal Kaosu, Çev. Nafer Ermiş, İmge Kitabevi, Ankara.

Berberick, S. (2010). The Objectification of Women in Mass Media: Female SelfImage in Misogynist Culture. The New York Sociologist.

Bergström, M. (2011). Casual dating online. Sexual norms and practices on French heterosexual dating sites. Journal of Family Research.

Binark, M. (Der.). (2015). Yeni Medya Çalışmalarında Araştırma Yöntem ve Teknikleri. İstanbul: Ayrıntı Yayınları.

Bullingham, L., \& Vasconcelos, A. C. (2013). 'The presentation of self in the online world': Goffman and the study of online identities. Journal of Information Science, 39(1), 101-112. doi:10.1177/0165551512470051 
Carter, C., \& Steiner, L. (2004). Critical readings: media and gender. Maidenhead: Open University Press.

Cesar, M. L. (13 Şubat 2016). Of Love and Money: The Rise of the Online Dating Industry. Erişim, 20 Şubat 2017. http://www.nasdaq.com/article/of-love-andmoney-the-rise-of- the-online-dating-industry-cm579616

Çık, A. (2017). Televizyon Reklamlarında Toplumsal Cinsiyet Rollerinin Yeniden Üretilmesi Üzerine Bir İnceleme (1970'lerden 2000'li Yıllara). ulakbilge, 5 (9), s.87-101. doi: 10.7816/ulakbilge-05-09-05

Döring, N., Reif, A., \& Poeschl, S. (2016). How gender-stereotypical are selfies? A content analysis and comparison with magazine adverts. Computers in Human Behavior, 55, s.955-962. doi:10.1016/j.chb.2015.10.001

Ellison NB, Heino R, Gibbs J. (2006). Managing impressions online: selfpresentation processes in the online dating environment. Journal of ComputerMediated Communication.

Elmacı, T. (2011). Yeni Türk Sinemasında Kadının Temsil Sorunu Bağlamında Gitmek Filminde Değişen Kadın İmgesi. İletişim Kuram ve Araştırma Dergisi, Güz 2011, Sayı: 33.

Enneli, Ç. (2010). Televizyondaki islam ve Gündelik Hayatın Siyaseti. Ankara Üniversitesi Rektörlüğü Yayınları : 255, Ankara. Retrieved from http://kitaplar. ankara.edu.tr/dosyalar/pdf/827.pdf

Evlenme ve Boşanma İstatistikleri (02 Mart 2017), Erişim 20 Mart 2017, http:// www.tuik.gov.tr/PreHaberBultenleri.do?id=24642

Gauntlett, D. (2008). Media, gender and identity: an introduction. London: Routledge.

Gencel Bek, M., Binark, M. (2000). Medyada Kadın, Ankara Üniversitesi, Kadın Sorunları Araştırma ve Uygulama Merkezi, Ankara.

Giddens, A. (1994). Mahremiyetin Dönüşümü, Çev. İdris Şahin, Ayrıntı Yayınları

Goffman, E. (1956). The presentation of self in everyday life. University of Edinburgh Social Sciences Research Center, https://monoskop.org/images/1/19/ Goffman_Erving_The_Presentation_of_Self_in_Ev eryday_Life.pdf

Göle, N. (1993). Modern mahrem: medeniyet ve örtünme. İstanbul: Metis.

Göle, N. (2002). Islam in Public: New Visibilities and New Imaginaries. Public Culture, 14(1), 173-190. doi:10.1215/08992363-14-1-173.

Hall, S. (1997). Representation: Cultural representations and signifying practices. London; Thousand Oaks, Calif.: Sage.

Hall, C. P., West, J. H., \& Mclntyre, E. (2012). Female self-sexualization in MySpace.com personal profile photographs. Sexuality and Culture, 16, s.1-16. 
Heino, R. D., Ellison, N. B., \& Gibbs, J. L. (2010). Relationshopping: Investigating the market metaphor in online dating. Journal of Social and Personal Relationships, 27(4), s.427-447. doi:10.1177/0265407510361614

Illouz, E. (2011). Soğuk yakınlıklar: duygusal kapitalizmin şekillenmesi. İstanbul: İletişim.

Kapidzic, S. (2013). Narcissism as a Predictor of Motivations Behind Facebook Profile Picture Selection. Cyberpsychology, Behavior, and Social Networking, 16(1), s.14-19. doi:10.1089/cyber.2012.0143

Kapidzic, S., \& Martins, N. (2015). Mirroring the Media: The Relationship Between Media Consumption, Media Internalization, and Profile Picture Characteristics on Facebook. Journal of Broadcasting \& Electronic Media, 59(2), s.278-297. doi:10. 1080/08838151.2015.1029127

Karaboğa, F. (2008). Evlenme Geleneğinin Değişen Karakteri Üzerine Bir inceleme: Sanal Ortam ve Evlenme. (Unpublished master dissertation). Gazi Üniversitesi. Ankara.

Kaymas, S. (2010). İslami Sanal Kamusal Alanda Kolektif Kimlik: İslami Evlilik Siteleri İçinden Kolektif Kimliği Okumak (Collective Identity in the Virtual Islamic Public Sphere: Reading a Collective Identity into the Islamic Marriage Agencies). Journal Of Yaşar University. https://hacettepe.academia.edu/SerhatKAYMAS

Kilbourne, J. (1991). Cant' Buy My Love: How Advertising Changes the Way We Think and Feel. NewYork: TouchstoneRockefeller Centre.

Kocamaner, H. (2017). Transformation of Islamic television in Turkey from the era of secularist state monopoly to family-focused programming under the conservative- Muslim AKP government. https://pomeps.org/2017/01/19/ transformation-of-islamic- television-in-turkey-from-the-era-of-secularist-statemonopoly-to-family-focused- programming-under-the-conservative-muslim-akpgovernment/

Lardellier, P. (2015). Virtual Religious Meetings, Actual Endogamy ... The Growing Success of Affinity Dating Sites. Heidelberg Journal for Religions on the Internet. Vol: 8.

Leeuwen, T. V., \& Jewitt, C. (2004). The handbook of visual analysis: Visual Meaning:a SocialSemioticApproach. London:SAGE.doi10.4135/9780857020062

Malik, S. (2014). Women's Objectification by Consumer Culture. International Journal of Gender \& Women's Studies, 2(4), s.87-102. doi:10.15640/ijgws. v2n4a5

Manning, J. (2013). Construction of Values in Online and Offline Dating Discourses: Comparing Presentational and Articulated Rhetorics of Relationship Seeking. Journal of Computer-Mediated Communication, 19(3), s.309-324. doi:10.1111/jcc4.12037 
Mattelart, A., \& Mattelart, M. (1995). Histoire des théories de la communication. Paris: Éd. La Découverte.

Marwick, A. E. (2012). The Public Domain: Surveillance in Everyday Life. Surveillance \& Society 9(4) http://www.surveillance-and-society.org

Meşe, i. (2015). "İslami bir moda dergisi örneğinde moda ve tesettür: Ne türden bir birliktelik?". Fe Dergi: Feminist Eleştiri. Cilt 7, Sayı. http://cins.ankara.edu.tr/

Nauck, B., Klaus, D. (2008). "Family Change in Turkey: Peasant Society, Islam, and the Revolution from Above. In: R. Jayakody et al. (Eds.), International Family Change. New York: Taylor \& Francis, s. 281-312.

Online Dating Statistics \& Facts. Erişim 18 Şubat 2017. https://www. datingsitesreviews.com/staticpages/index.php?page=Online-Dating- IndustryFacts-Statistics

Özdemir, Z., Çetinkaya, A. (2015). Türkiyeıde Sosyal Medyaıda Kimlik İnşası: Özçekim Kullanımı (Building Social Media Identity in Turkey: Using Selfies). Turkish Studies.Vol.10. Issue.14. doi: 10.7827/TurkishStudies.8913

Özüstün, E. (2015). Mediaıs Effect on Online Dating Practices: Turkish TV Marriage Programs and Online Dating as a Medium in Degim, A. Johnson, J. \& $\mathrm{Fu}, \mathrm{T}$. (Eds.), Online Courtship: Interpersonal Interactions Across Borders, Theory On Demand, No:16. https://www.academia.edu/13917843/Online_Courtship_ Interpersonal_Interactions_A cross_Borders

Pala, S. (2015). Evlilik Sitesi Kullanıcılarının Karakteristikleri ve Kullanım Motivasyonları (Characteristics and Using Motivations of Marriage Website Users) (Unpublished master dissertation). Selçuk Üniversitesi. Konya.

Papacharissi, Z. (2009). The virtual geographies of social networks: a comparative analysis of Facebook, Linkedln and ASmallWorld. New Media \& Society, 11(1-2), s.199-220. doi:10.1177/1461444808099577

Piela, A. (2011). Beyond the Traditional-Modern Binary: Faith and Identity in Muslim Women's Online Matchmaking Profiles. CyberOrient, Vol. 5, Iss. 1. http://www.cyberorient.net/article.do?articleld $=6219$

Ramirez, A., Sumner, E. M., Fleuriet, C., \& Cole, M. (2014). When Online Dating Partners Meet Offline: The Effect of Modality Switching on Relational Communication Between Online Daters. Journal of Computer-Mediated Communication, 20(1), s.99- 114. doi:10.1111/jcc4.12101

Shove \& Warde. (1998). Inconspicuous consumption: the sociology of consumption and the environment. http://www.lancaster.ac.uk/fass/resources/ sociology- online- papers/papers/shove-warde-inconspicuous-consumption.pdf

Smith, A \& Anderson, M. (29 Şubat 2016). 5 facts about online dating. Erişim 20 Şubat 2017, http://www.pewresearch.org/fact-tank/2016/02/29/5-facts-aboutonline-dating/ 
Strano MM. User descriptions and interpretations of self- presentation through Facebook profile images. Cyber-Psychology: Journal of Psychosocial Research on Cyberspace 2008; 2: Article 1.

Toma, C. L., Hancock, J. T., \& Ellison, N. B. (2008). Separating Fact From Fiction: An Examination of Deceptive Self-Presentation in Online Dating Profiles. Personality and Social Psychology Bulletin, 34(8), s.1023-1036. doi:10.1177/0146167208318067

Toma, C. L., \& Hancock, J. T. (2010). Looks and Lies: The Role of Physical Attractiveness in Online Dating Self-Presentation and Deception. Communication Research, 37(3), 335- 351. doi:10.1177/0093650209356437

Toy Par, A. (2005) "Les effets de la modernisation sur la société turque des années 60 à travers les films réalistes", İleti-ş-im, Galatasaray Üniversitesi İletişim Fakültesi Hakemli Dergisi sayı: 3, s. 65-80.

Tütüncü, F. (2007). Güzel Ahlaklı Biriyle Hayırlı Bir izdivaç için: IslamiEvlilik Siteleri, Dönüşen Mahremiyetler ve Kadın Öznelliği içinde Binark, M. Yeni Medya Çalışmaları. Dipnot Yayınları, Ankara.

Uğur Tanrı̈ver, Hülya (2007). Medyada Kadınların Temsil Biçimleri ve Kadın Hakları Ihlalleri, Kadın Odaklı Habercilik, Haz. Sevda Alankuş, İstanbul: IPS İletişim Vakfı Yayınları.

Uğur Tanrı̈ver, Hülya; Sözeri, Ceren; Vitrinel, Ece; Sunar, Melda; Barış Kara; "Medyada Kadın Temsilleri", Medyada Cinsiyetçiliğe Son, MEDiz, İstanbul, 2008.

Uski, S., \& Lampinen, A. (2016). Social norms and self-presentation on social network sites: Profile work in action. New Media \& Society, 18(3), s.447-464. doi:10.1177/1461444814543164

Vardı, R. (2012). Internet Kullanıcılarının Dini İçerikli Kullanım Alışkanlıkları. Harran Üniversitesi Illahiyat Fakültesi Dergisi, Yı: 17, Sayı 28, Temmuz-Aralık 2012. http://www.anadiliegitimi.com/download/article-file/257706

Varol, S. F. (2014). Medyada Yer Alan Temsillerin Kimlik Edinme Sürecindeki Rolü. The Journal of Academic Social Science Studies. Number: 26, s. 301-313, Summer II. http://dx.doi.org/10.9761/JASSS2398

Walther, J. B. (1996). Computer-mediated communication: Impersonal, interpersonal, and hyperpersonal interaction. Communication Research, 23, $3-43$

Wang, Y. (2011). Internet dating sites as heterotopias of gender performance: A case study of Taiwanese heterosexual male daters. International Journal of Cultural Studies, 15(5), s. 485-500. doi:10.1177/1367877911422855 
Whitty, M. (2007). Revealing the 'real' me, searching for the 'actual' you: Presentations of self on an internet dating site. Computers in Human Behavior, 24,4 , s. 1707-1723.

Yıldız, Ö. E., Deneçli, C., Deneçli, S. (2011). A General Outlook of Conjugal Union and Marriage in Turkey in The Context of Popular Culture, New Media, The Turkish Online Journal of Design, Art and Communication - TOJDAC. 1:1 http:// www.tojdac.org/tojdac/VOLUME1-ISSUE1_files/tojdac_v01i101.pd

Yoder, S. (19 Şubat 2014). How online dating became a $\$ 2$ billion industry. Erişim 20 Şubat 2017, http://theweek.com/articles/450841/how-online-dating-became2-billion- industry\#axzz34cTWJ0do

Zheng, W., Yuan, C., Chang, W., \& Wu, Y. J. (2016). Profile pictures on social media: Gender and regional differences. Computers in Human Behavior, 63, s.891-898. doi:10.1016/j.chb.2016.06.041 